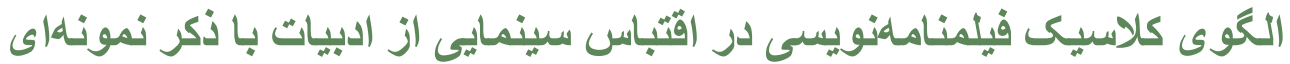

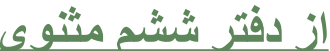

\title{
Mesnevî̀nin Altıncı Defterinden Bir Örnekle Edebiyatın Sinemaya Uyarlanmasında Senaryo Yazımının Klasik Paradigması
}

\section{The Classic Paradigm of Screenwriting in the Cinematic Adaptation of Literature: An Example From the Sixth Book of Rumi's Masnavi}

Davoud SPARHAM $^{1}$ [1], Fatmeh KOLAHDOUZ ${ }^{1}$ []

'Istanbul University, Faculty of Literature, Department of Eastern Languages and Literatures, Department of Persian Language and Literature, Istanbul, Turkey

${ }^{2}$ Tahran, Iran

ORCID: D.S. 0000-0002-2292-1332; F.K. 0000-0002-4610-1558

Sorumlu yazar/Corresponding author:

Davoud SPARHAM (Prof. Dr.),

Istanbul University, Faculty of Literature

Department of Eastern Languages and

Literatures, Department of Persian Language

and Literature, Istanbul, Turkey

E-posta:d_sparham@yahoo.com

Başvuru/Submitted: 31.03 .2021

Revizyon Talebi/Revision Requested:

13.04.2021

Son Revizyon/Last Revision Received:

25.05.2021

Kabul/Accepted: 25.05.2021

Atıf/Citation: Sparham, Davoud ve Kolahdouz, Fatma. "The Classic Paradigm of Screenwriting in the Cinematic Adaptation of Literature: An Example From the Sixth Book of Rumi's Masnavi". Şarkiyat Mecmuası - Journal of Oriental Studies 39 (2021), 37-54

https://doi.org/10.26650/jos.90708

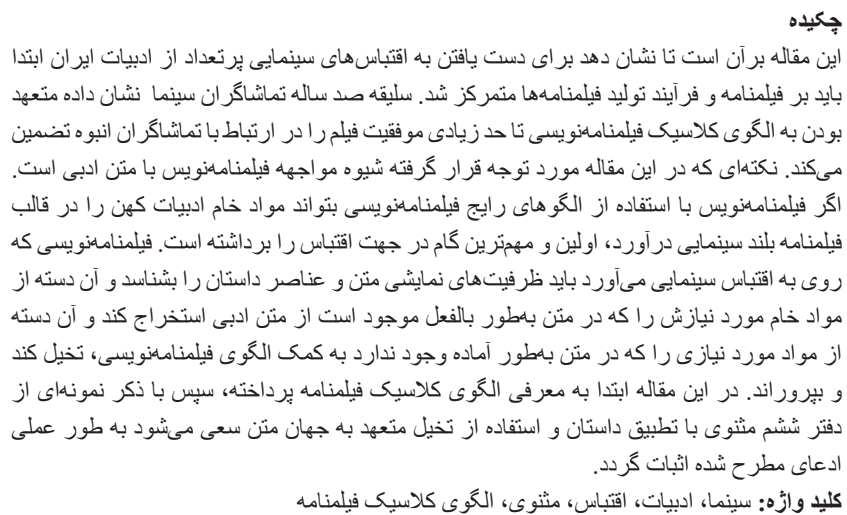

öz

Bu makale İran edebiyatının çok sayıda sinema uyarlamasını oluşturmak için öncelikle senaryolara ve senaryoların oluşum sürecine odaklanılması gerektiğini göstermeyi amaçlamaktadır. Yüz yıllık sinema izleyicilerinin zevki, klasik senaryo yazma paradigmasına bağlı kalmanın büyük izleyici kitlesine göre filmin başarısını neredeyse güven altına aldığını göstermiştir. Bu makalede ele alınan husus, senaristin edebi metini ele alış biçimidir. Eğer senarist yaygın senaryo yazma paradigmalarını kullanarak klasik edebiyatın ham maddelerini uzun metrajı bir film senaryosuna dönüştürebilirse uyarlama yolundaki ilk ve en önemli adımı atmış olur. Sinema uyarlamasına dönüştüren bir senaristin, metnin drama değer ölçüleri ile hikaye unsurlarını bilmesi, metinde mevcut olan gerekli ham maddeleri edebi metinden çıkarması ve metinde bulunmayan gerekli materyali 
senaristin paradigma yardımıyla hayal etmesi ve beslemesi gerekir. Bu makalede öncelikle senaryonun klasik paradigma tanımı yapılacak ve ardından Mesnevînin altıncı defterinden bir örnekle hikaye uygulaması ve metin dünyasına bağlı hayali kullanımlar ile iddialar kanıtlanmaya çalışılacaktır.

Anahtar kelimeler: Sinema, Edebiyat, Uyarlama, Mesnevî, Klasik senaryo paradigması

\begin{abstract}
The present paper aims to demonstrate that scholars should focus on screenplays and their production processes before attempting to create numerous cinematic adaptations of Iranian literature. The century old tastes of cinema audiences indicate that a commitment to the classic paradigm of screenwriting can almost guarantee the success of a film and assure its ability to attract large audiences. This paper probes the ways in which screenwriters encounter literary texts. Screenwriters are deemed to have taken the most important step toward successful cinematic adaptation if they can use traditional screenwriting paradigms to turn the raw materials of old literary texts into long movie scripts. Screenwriters attempting cinematic adaptations must apprehend the dramatic potential of text sand their narrative elements, extract the essential raw material available in the literary text, envision its refinement, and use the screenwriting paradigm to develop the requisite aspects lacking in the original text. The present paper initially introduces the classic paradigm of screenwriting and subsequently attempts to offer practical evidence of its claims using the example of the sixth book of Rumi's Masnavi, adapting its plot, and employing an imagination committed to the world of the text.
\end{abstract}

Keywords: Cinema, Literature, Adaptation, Masnavi, Screenplay classic paradigm

\title{
EXTENDED ABSTRACT
}

The popularity of the modern art and craft of cinema has been established across the world, including Iran, for more than a century. Cinema is influenced by the ancient heritage of the rich histories, civilizations, cultures, and arts of nations. Despite centuries lapsing since they were written, significant literary works still incite new ideas and become resources for new art forms such as cinema. Numerous screenplays have been created in Iran inspired by ancient literary texts, and all such adaptations are regarded as superlative cinematic works. A screenwriter can observe a multitude of human ideas and delve deeply into serious human issues through encounters with the abundance and richness of ancient Persian literature. The structures of such fictional and educational literary works cannot be adapted to cinema in their present raw forms. Therefore, a screenwriter must attempt to apply the cinematic framework and accord the raw material of the ancient story the components of a feature film. The works of the great mystic Rumi, especially this renowned Masnavi have inspired screenwriters over the last few decades. The plot and structure of Masnavi present distinct narratives each of which conveys a mystical and spiritual message. Notably, Rumi's stories are structurally suited to conversion into scripts/films. However, the screenwriter must know special cinematic techniques and comprehend Masnavi's nuanced text to achieve an apt adaptation. The screenwriter must use the power of imagination to consciously face Masnavi to be able to turn its raw material of fiction into new and modern screenplays. This paper initially introduces the classical patterns of screenwriting. Subsequently, it demonstrates how the ancient intellectual heritage of a text (Masnavi) can be transformed through imagination into new art. This objective is accomplished through the example of story from the sixth book; 


$$
\text { (حكايت آن شخصى است كه خو اب ديد كه آنجه مىطلبى از يسار ، به مصر وفا شود) }
$$

This anecdote, a man travels to Egypt and Baghdad in search of treasure and finally realizes that treasure can be found in his own home. 


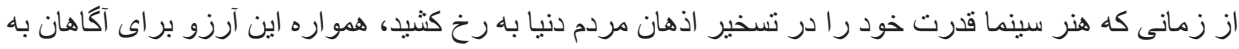

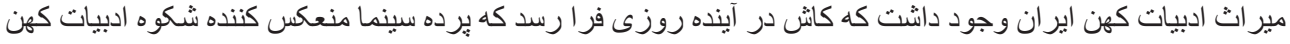

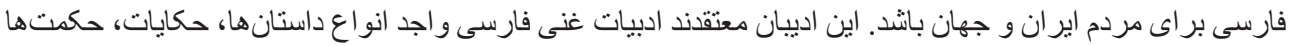

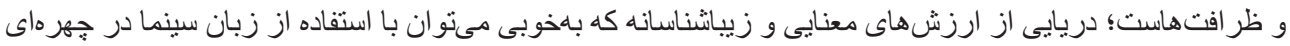

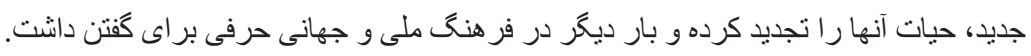

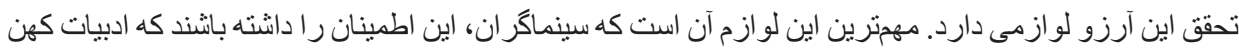

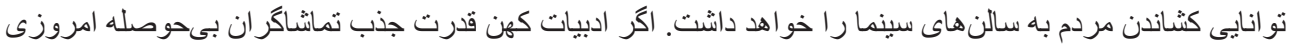

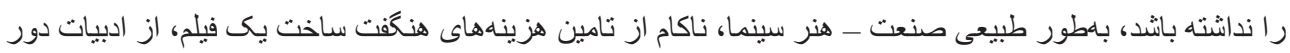

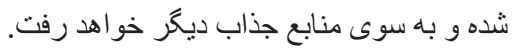

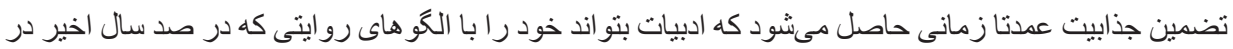

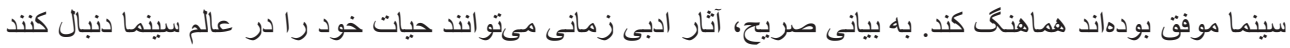

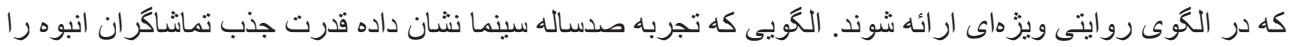

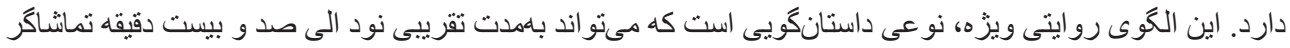

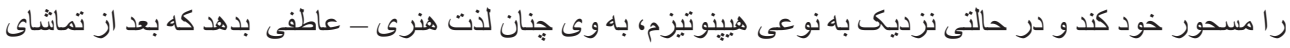

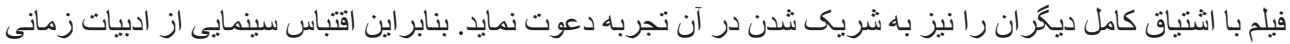

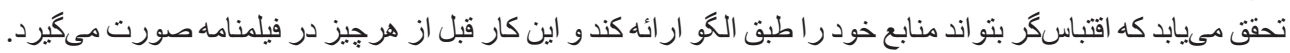

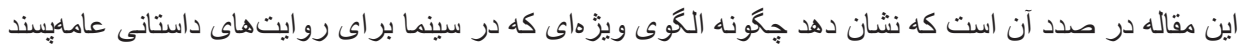

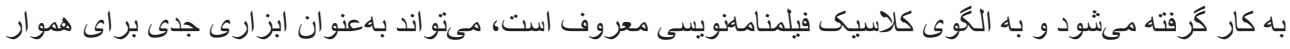

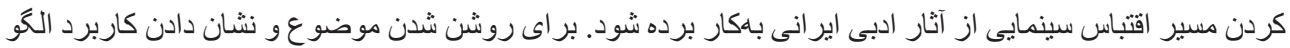

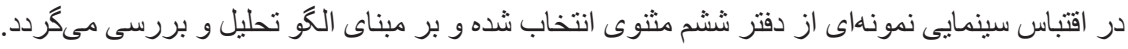

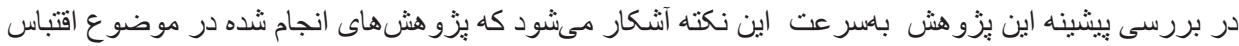

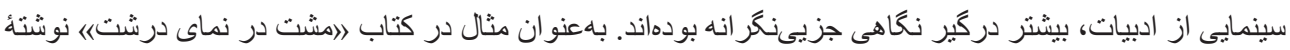

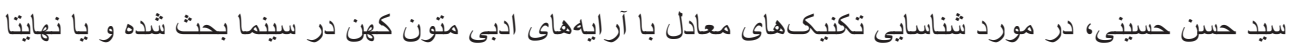

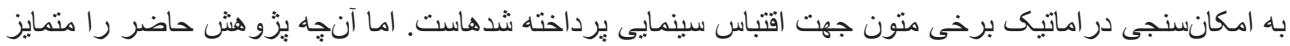

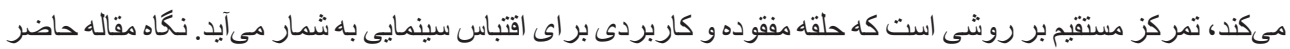

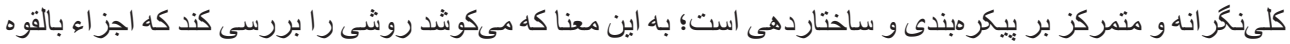

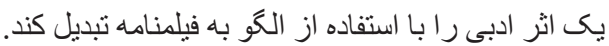

\section{الكُوى كلاسيك فيلمنامهنويسى هيست؟}

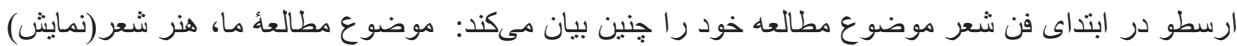

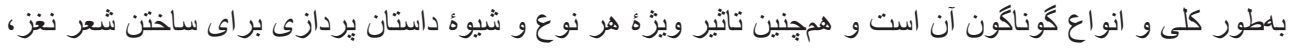

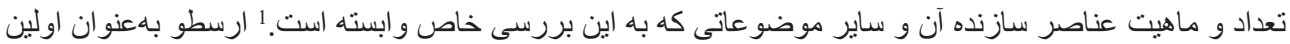

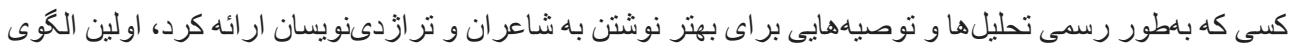

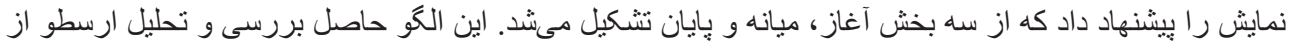

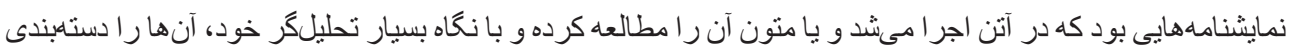

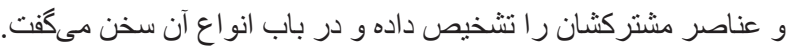

1 1 ارسطو، بوطبقا/ترازدى، نرجمه هلن اوليايى نيا (اصفهان: نشر فردا، 1386)، 41. 
دو هز ار سال بعد از ارسطو، زمانى كه يديدهاى بانام سينما در جهان مدرن، داستانكويى و در ام را با با هم در آميخت

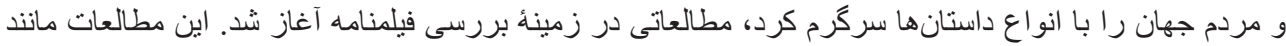

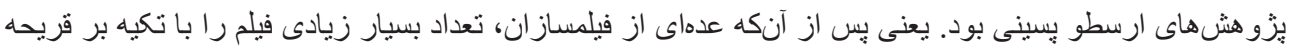

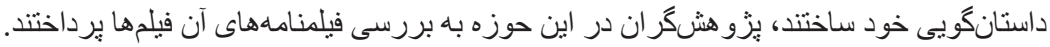

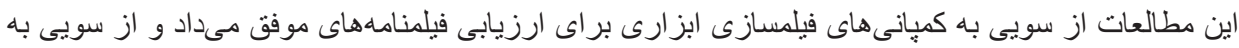

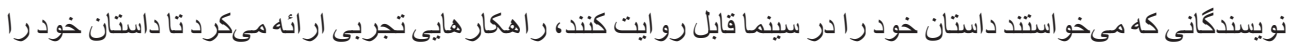

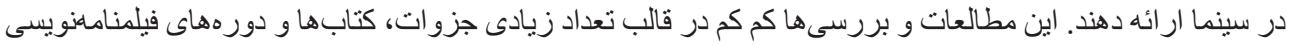

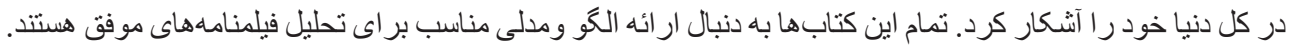

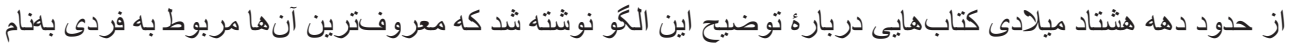

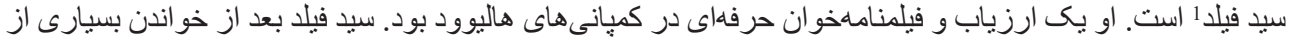

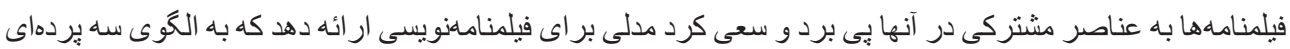

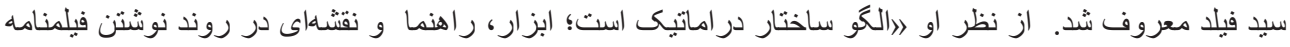

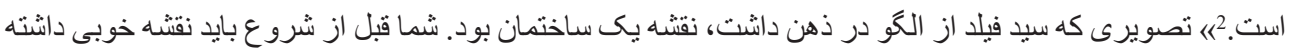

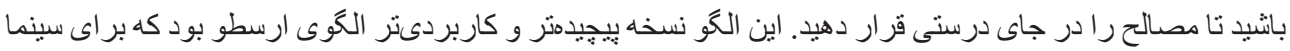

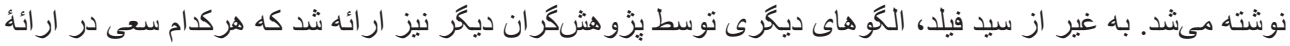

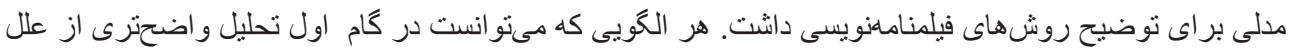

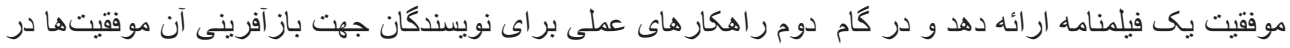

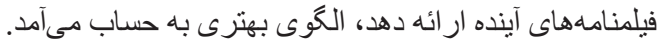

\section{Syd Field - 1}

معمو لا الكو هاى فيلمنامهنويسى از سه بخش تشكيل شدهاند:

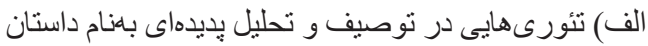

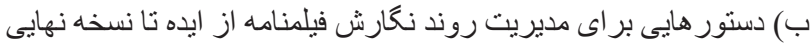

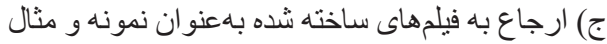

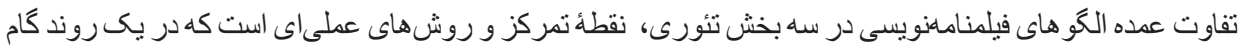

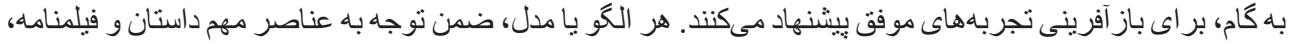

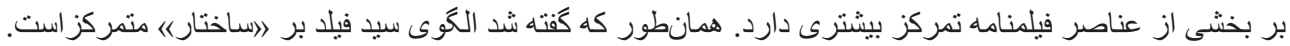

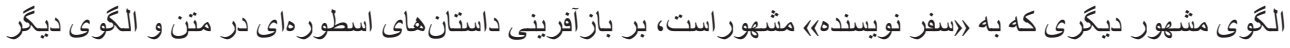

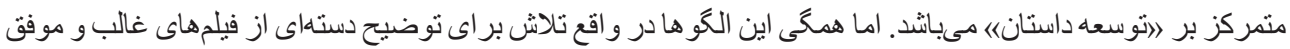

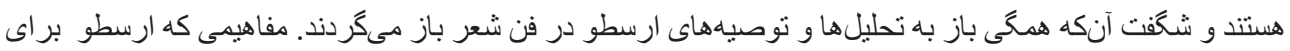

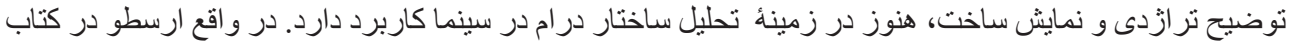

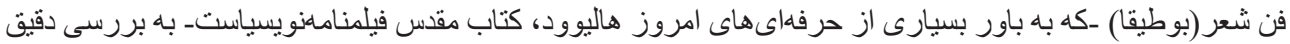

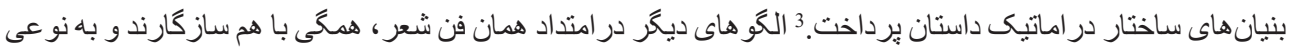

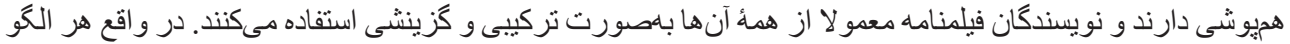

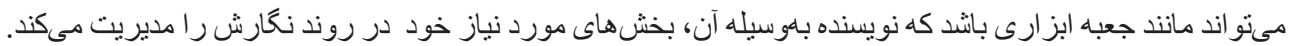




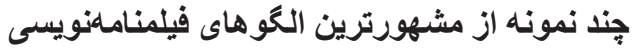

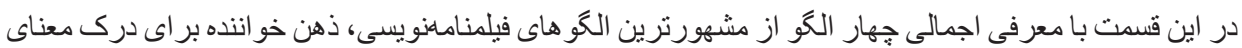

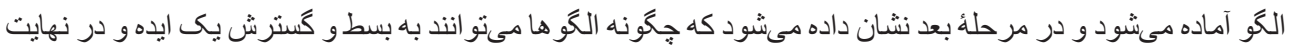
اقتباس از يك متن كهن كمى كنتد.

\section{Michael Tierno - 2}

الف) الكوى عناصر داستان

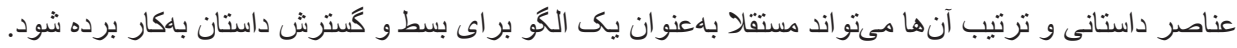

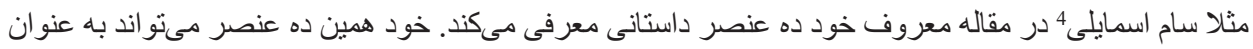

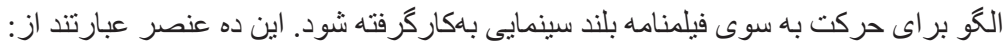

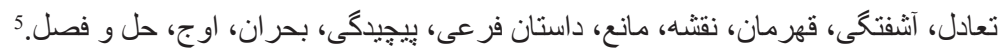

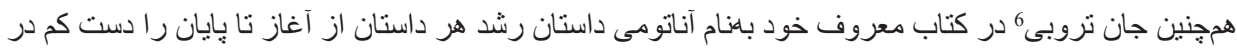

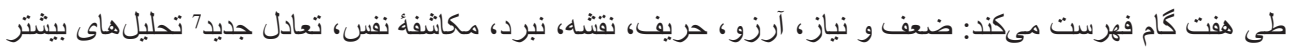

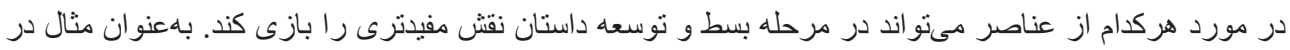

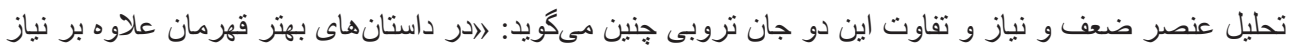

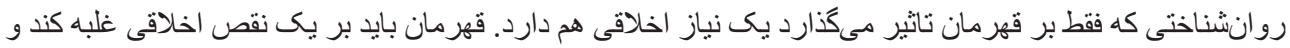

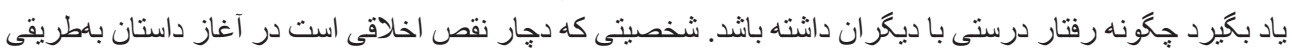

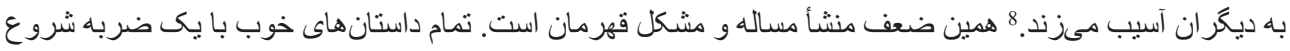

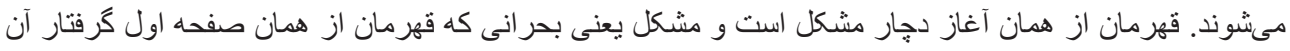

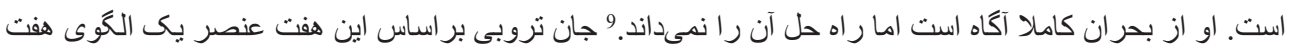

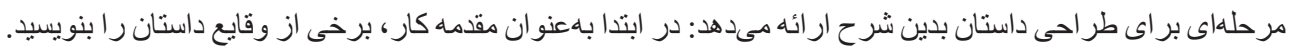

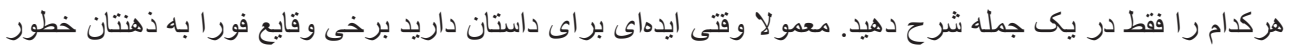

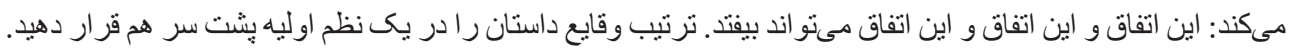

1. با تعيين مكاشفه نفس (روانشناختى و اخلافى) در پِايان داستان شروع كنيد. 2.

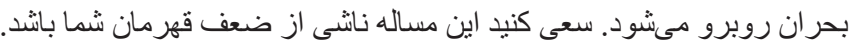

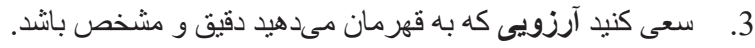

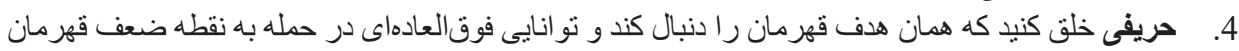
داشته باشد. نقشهاى خلق كنيد كه قهرمان را ملزم به كنشهايى جند اما علاوه بر آن ملزم به اصلاح آن در صورت عدم كار ايى نقشه اوليه مئكند. 6. قهرمان و حريف اصلى در نبرد بايد حضور داشته باثند. در جنى عملى يا لفظى. هر نبردى كه انتخاب

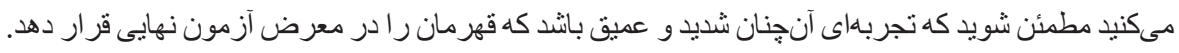

$4 \quad$ Sam Smiley

5 سام اسمايلى، "ويزه نامه رو ايت و ضد روايت،"مقاله داستان، ترجمه منصور بر اهيمى، مجله فار ابى (تهران: نشر فار ابى، 1377)، 39.

6 John Truby

7 


\section{7.}

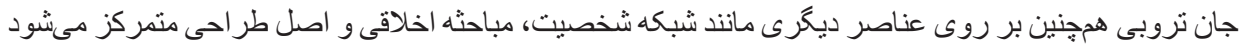

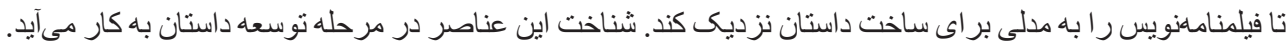

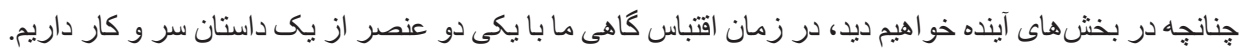

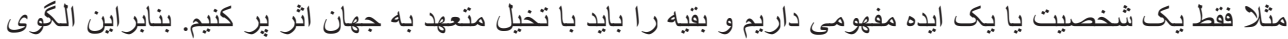

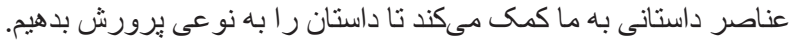

\section{ب) الكَوى فيلمنامهنويسى سله يردداى سبد فيلا}

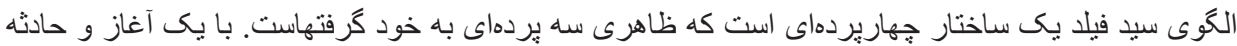

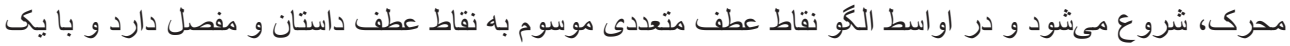

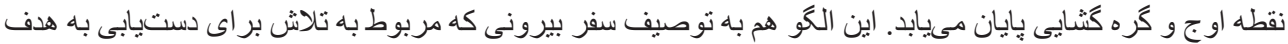

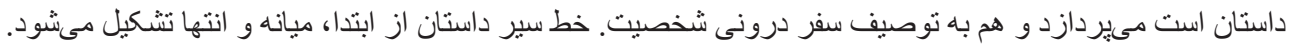

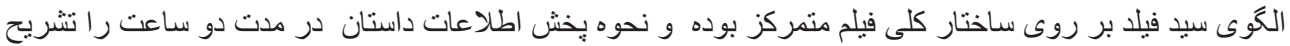

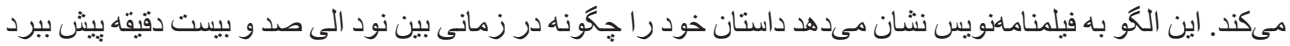

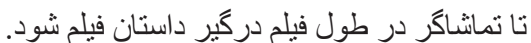

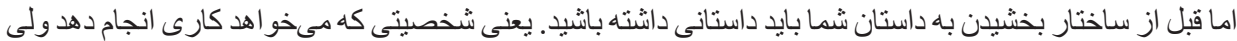

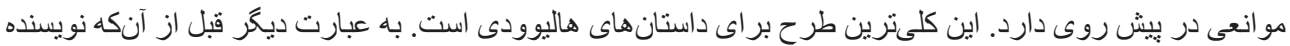

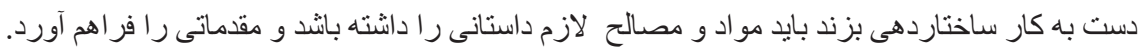

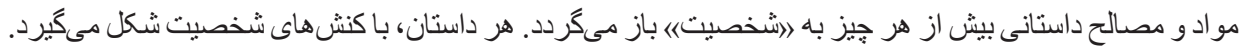

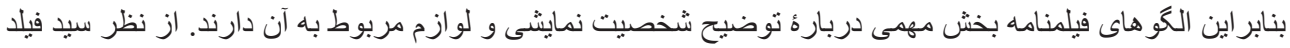

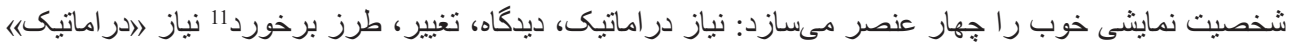

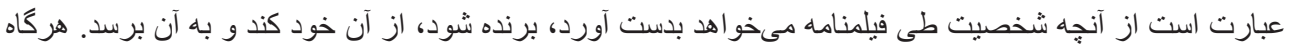

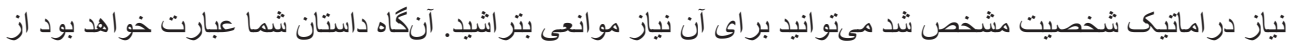

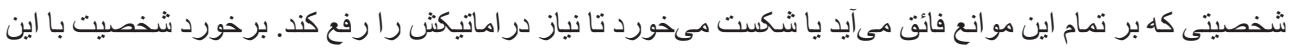

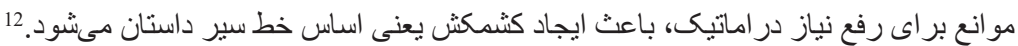

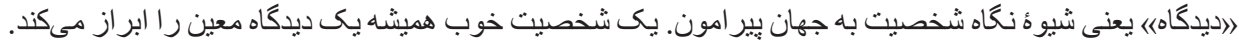

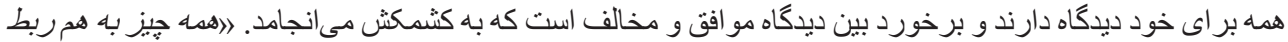

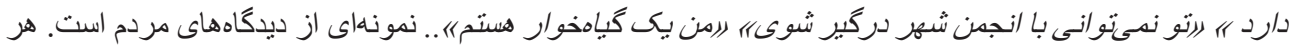

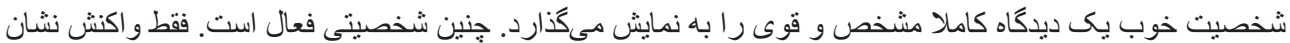
نمىدهد بلكه بر اساس ديدكاهش عمل مىكند.

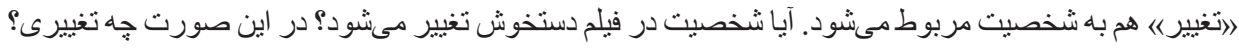

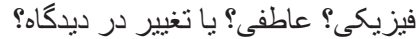

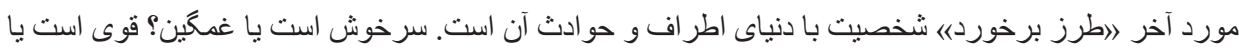

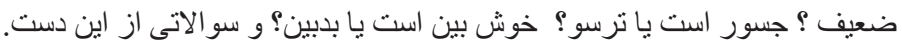

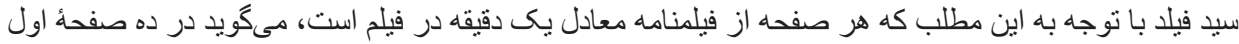

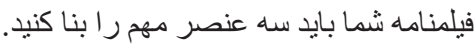




$$
\begin{aligned}
& \text { 1. شخصيث اصلى كيست؟ يعنى داستان شما دربار جها جه كسى است؟ }
\end{aligned}
$$

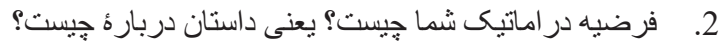

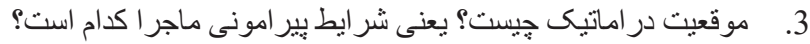

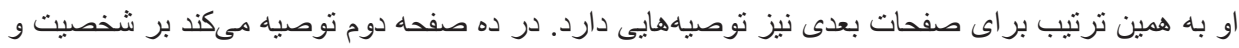

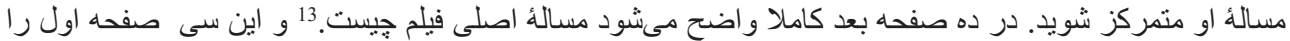

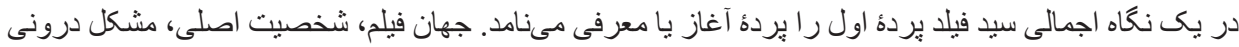
شخصيت و مشكل بيرونى شخصيت در اين برده مشخص مىشود. شخصيت در محيط زندكى خود شناسانده مى نشود تا

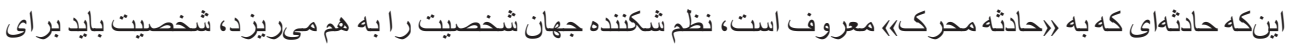

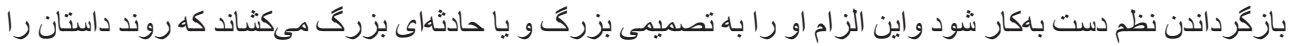

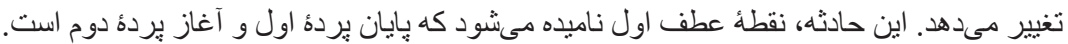

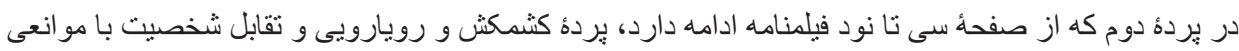

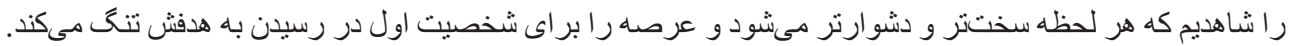

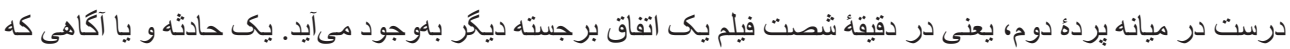

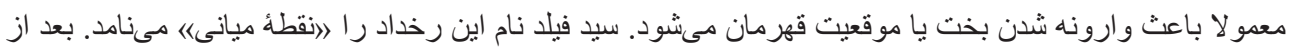

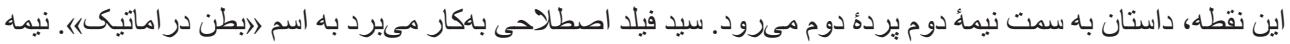

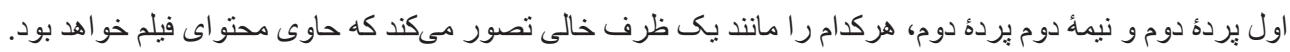

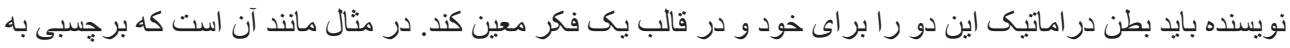

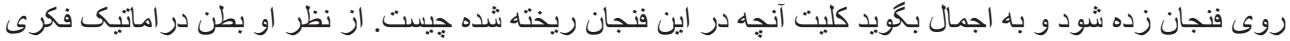

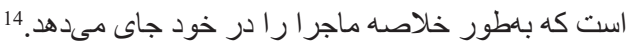

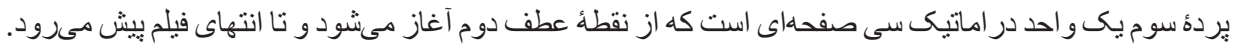

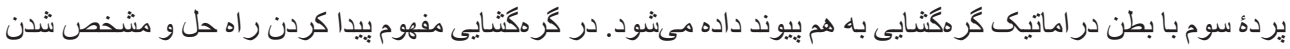

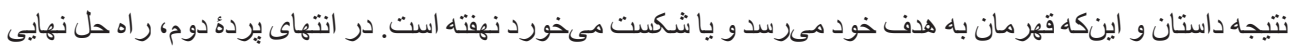

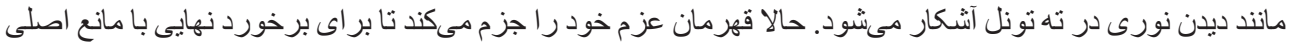

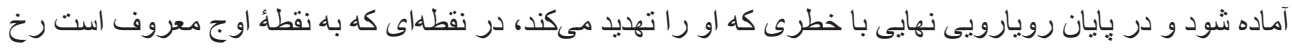

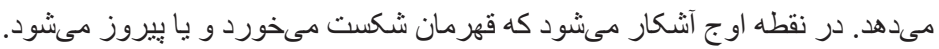

\section{ج) الكُوى سفر نويسنده، كريستوفر ووكلر 15}

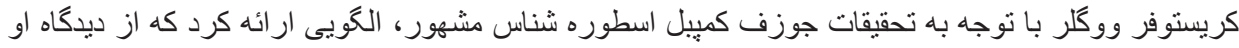

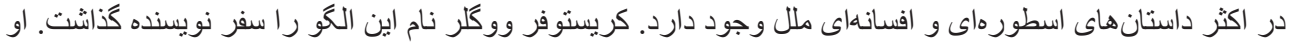

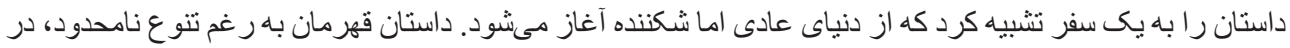

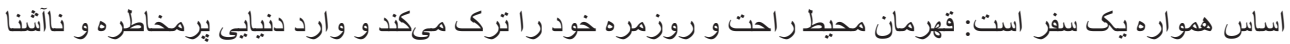

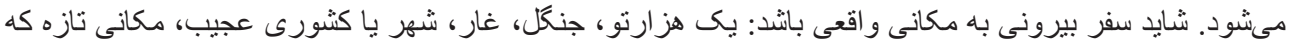

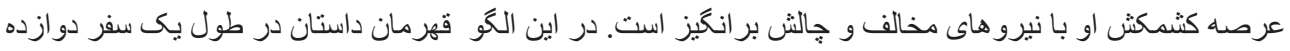
مرحله را يشت سر مكىكذارد.

15 Christopher Vogler

13

14

16 كريسنوفر ووكلر، سفر نوبينده، ترجمه محمد كذر آبادى (تهران: نشر مينوى خرد، 1391)، 39. 


\section{1. د دنباى عادى: خانه و مأمن قهرمان، جايى كه در آن احساس آسودكى مىكند.

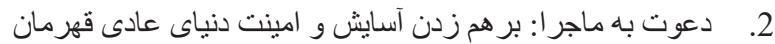

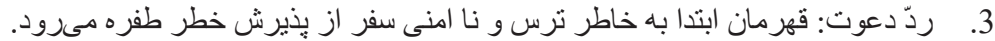

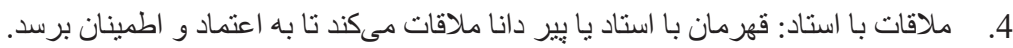

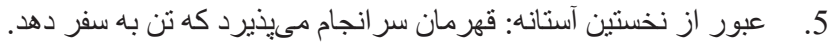

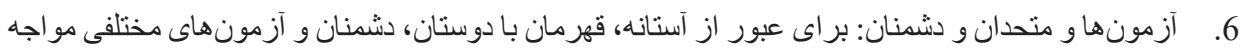

مىشود.

7. ر راهيابى به زُرفترين غار : قهرمان بايد آمادگى و امكانات لازم براى كذر از سخترين مرحله سفر را

داشته باشند.

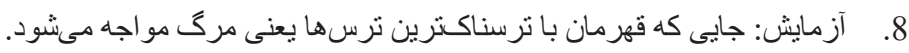

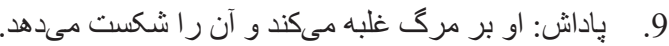

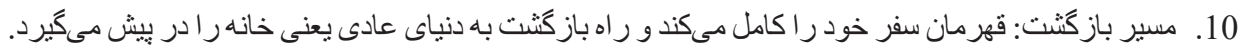

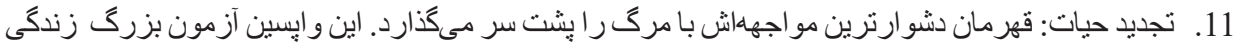

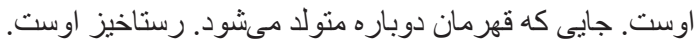

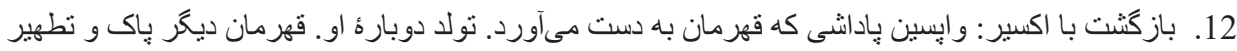

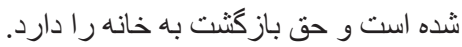

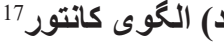

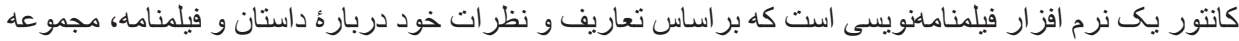

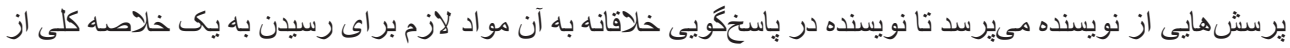

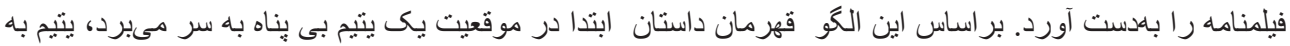

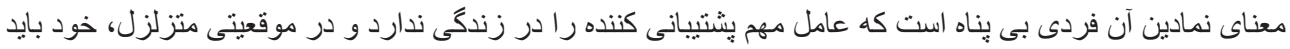

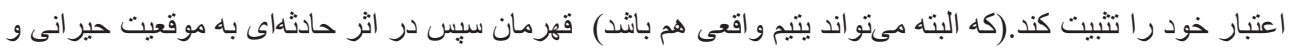

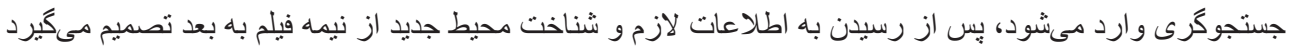

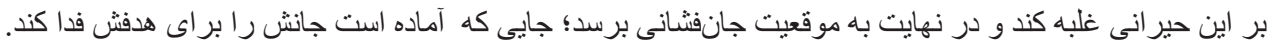

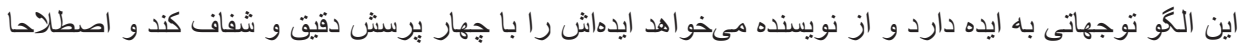

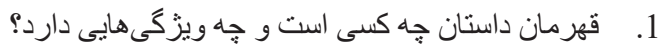

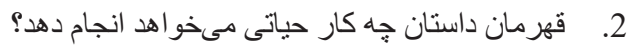

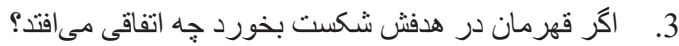

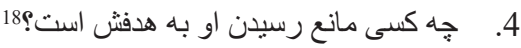

همجنين اين الكو ييشنهاد مىكند داستان خود را دان در قالبى مانند قالب زير بيان كنيد:

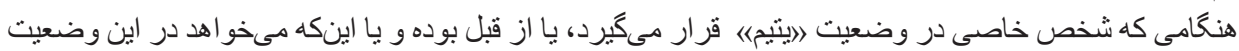

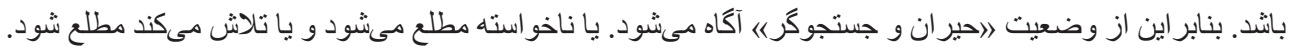

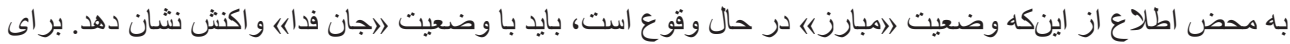

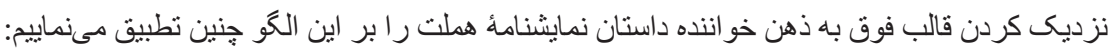

17 contour

شهر ام كهر ابى، الكوى بيكره بندى فيلمنامه هاى موفق: بر اساس الكوى گكترش ايده داستانى (تهر ان: نشر افراز، 1391)، 23. 


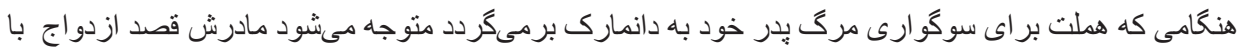

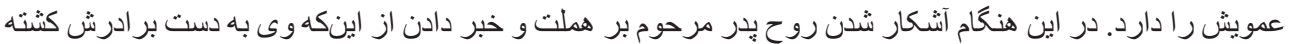

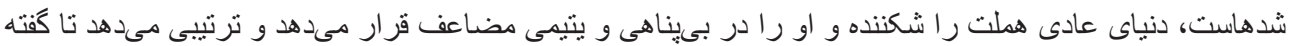

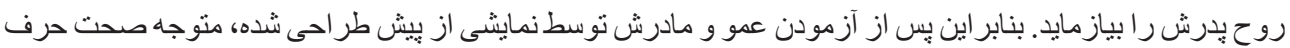

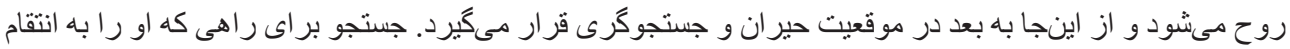

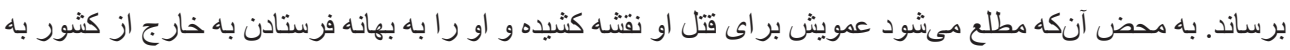

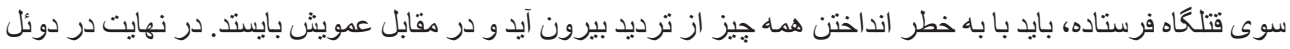

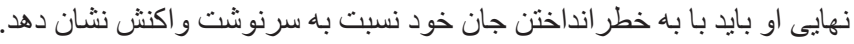

\section{اقتباس سينمايى به معناى ياستخ دادن به انتظارات الكو}

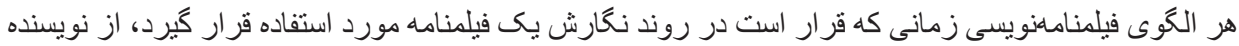

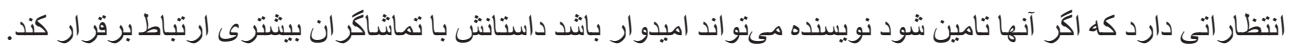

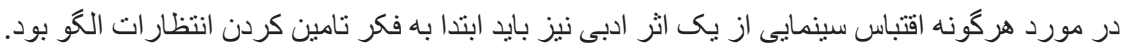

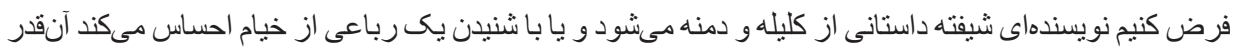

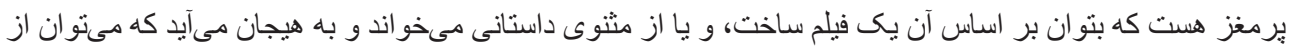

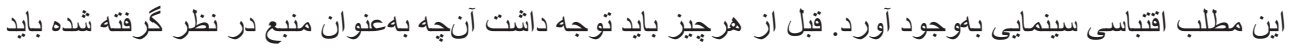

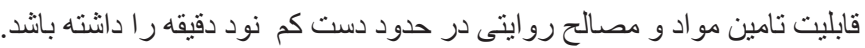

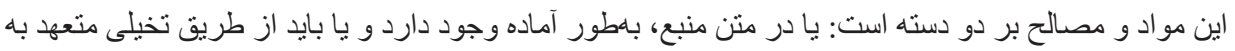

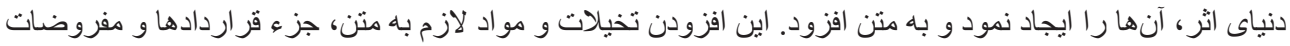

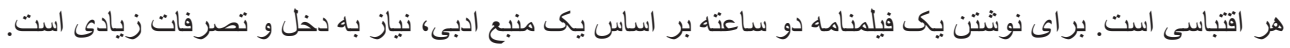

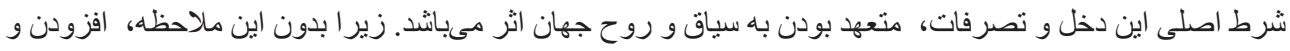

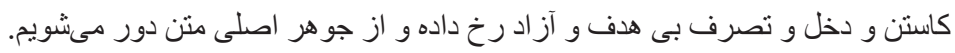

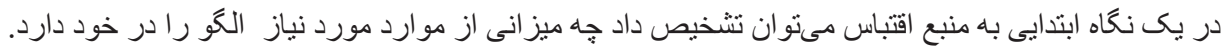

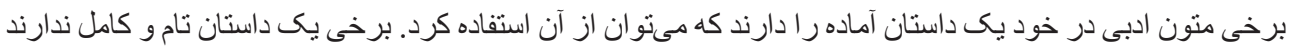

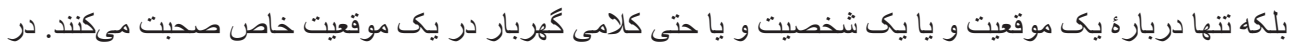

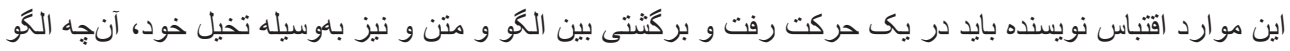

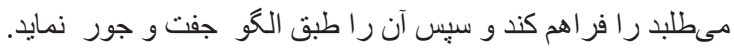

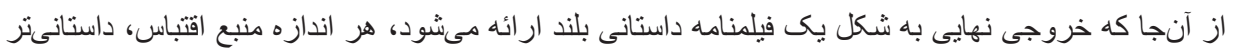

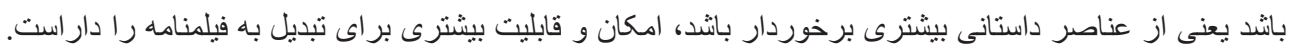

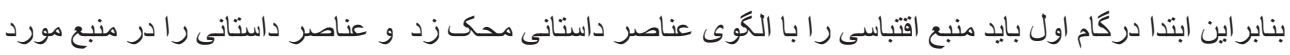

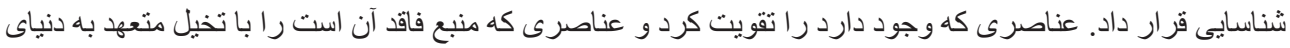

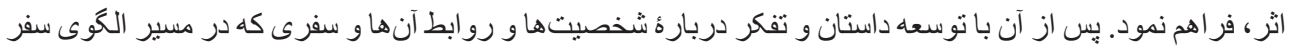

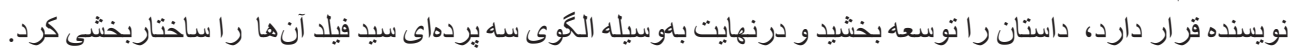

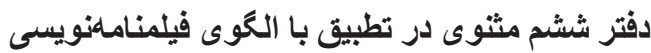

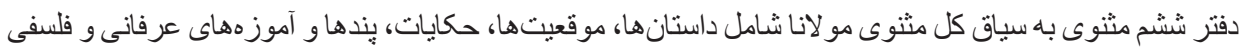

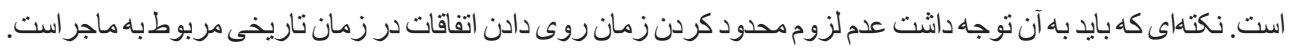

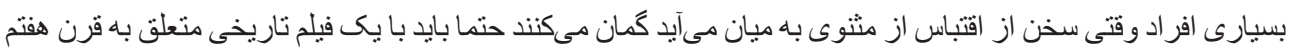


سر و كار داشته باشند. در صورتىكه دو ام مثثوى تا عصر حاضر و جهانكير شدن انديشه و نحاه مو لانا، خود حاكى از آن

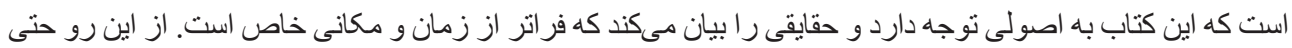

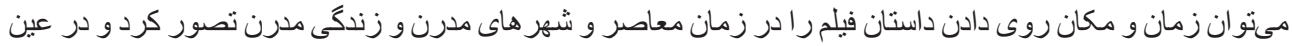

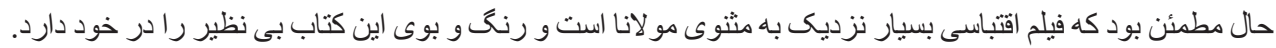

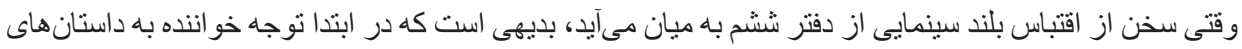

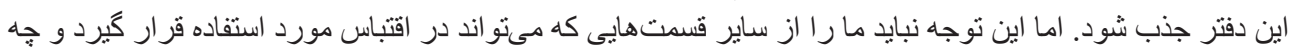

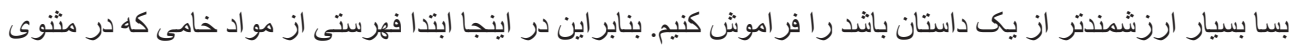

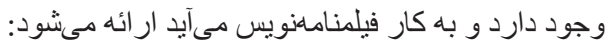

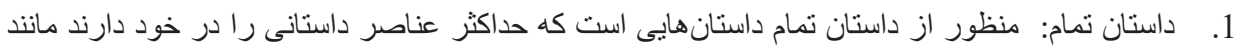

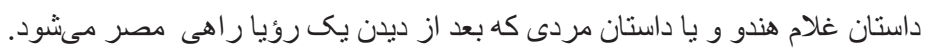

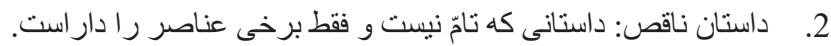

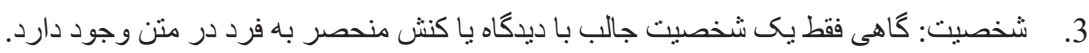

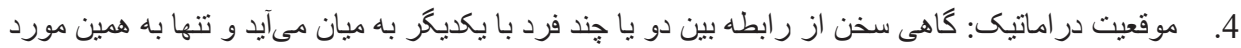

اكتفا مىشود و موقعيت تبديل به داستان نمىشود.

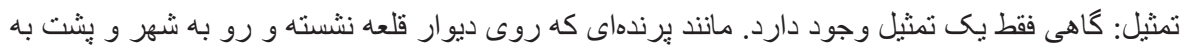

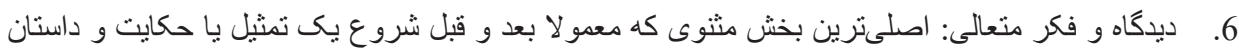

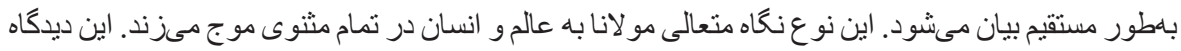

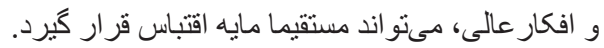

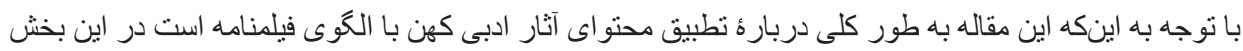

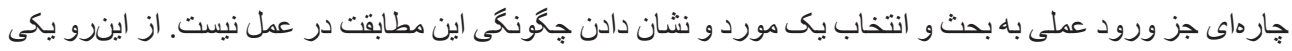

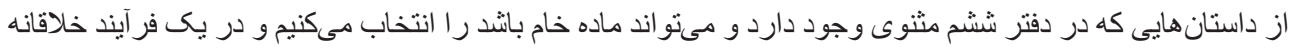

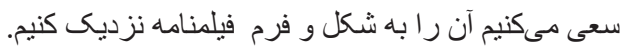

\section{خلاصه داستان}

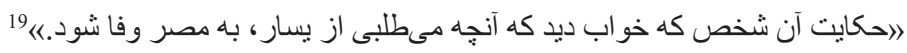

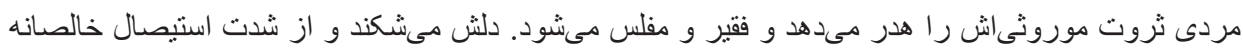

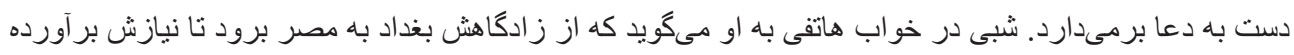

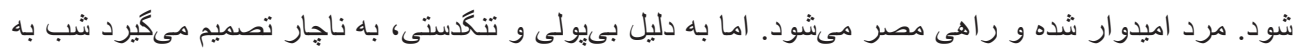

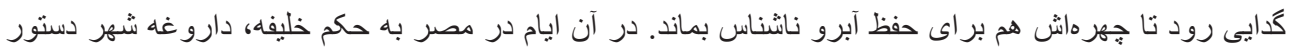

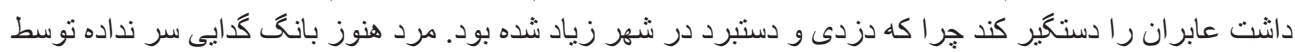

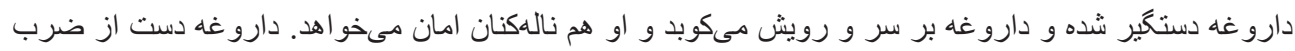

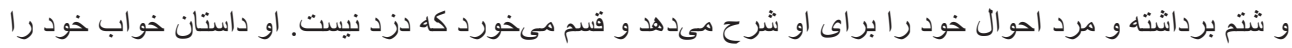

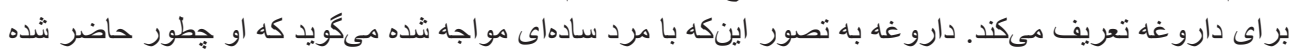

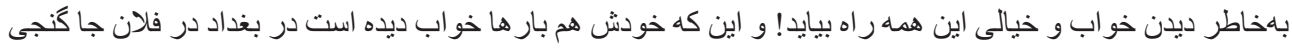

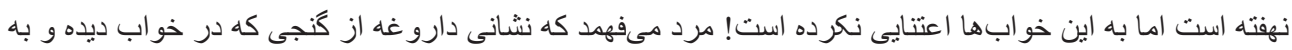

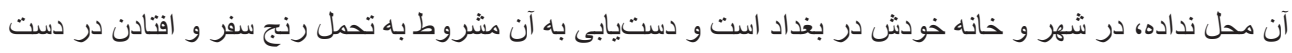

19 جلال الدين محمد بن محمد مولوى، مثنوى معنوى، تصحيح رينولد نيكلسون (تهر ان: نشر ييمان، 1380)، 941. 
دارو غه بوده است. سيّ راهى ديار خود مىشود و آن كنج را درست در جايى كه دارو غه به او كفته بود مىيابد و از تنكدستى و فلاكت نجات مى ديابد.

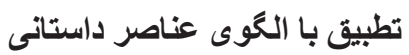

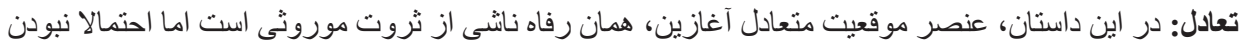

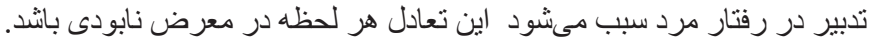

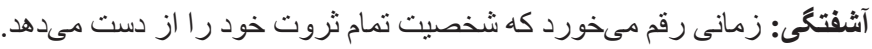

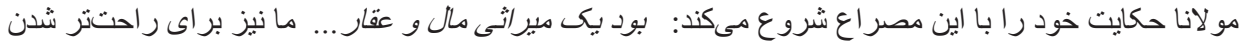

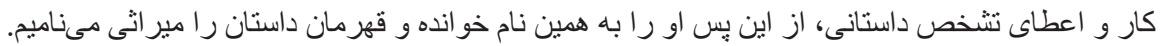

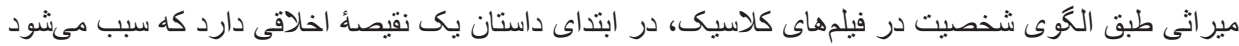

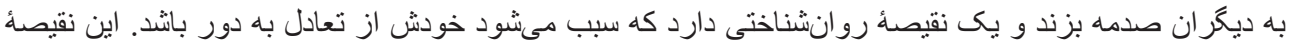

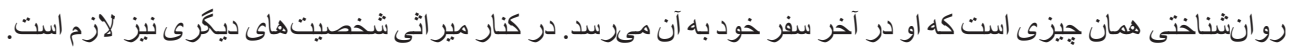

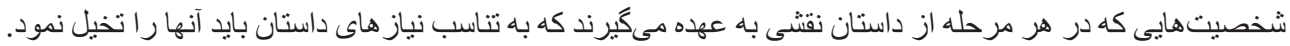

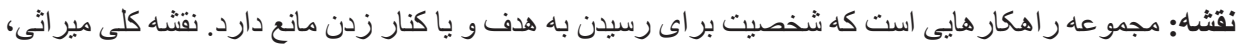

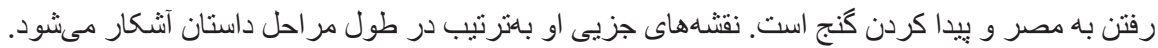

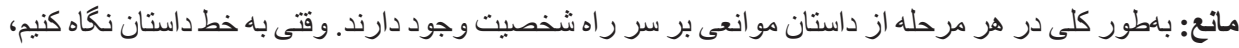

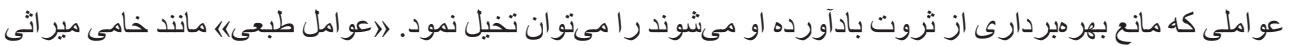

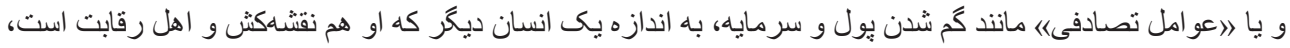

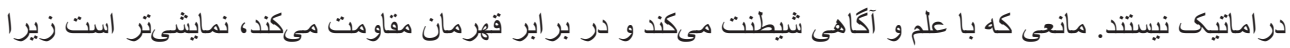

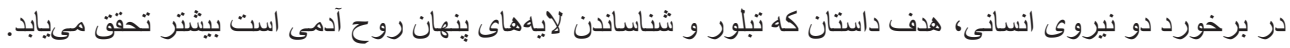

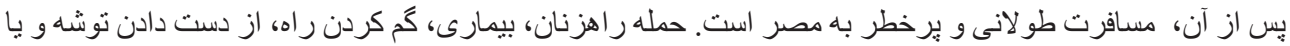

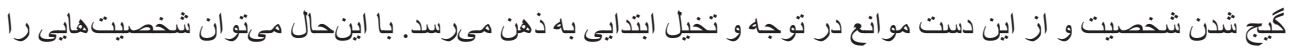

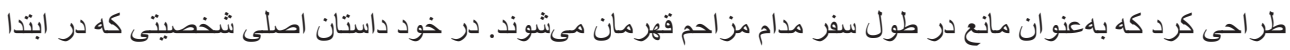

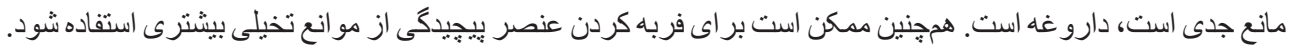

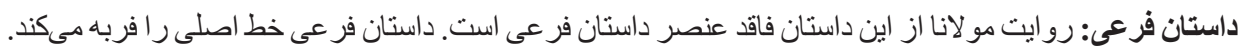

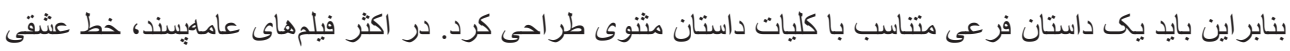

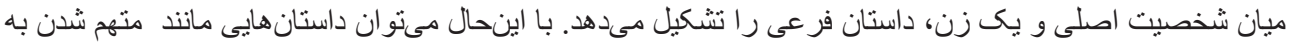

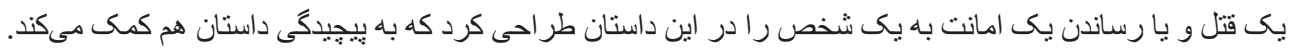

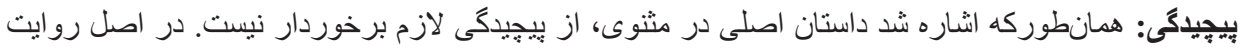

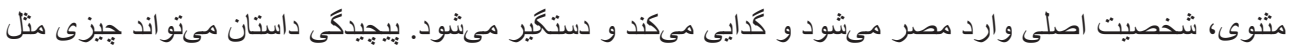

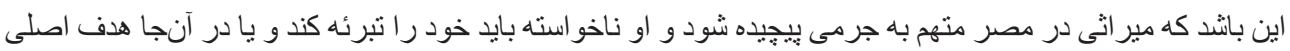

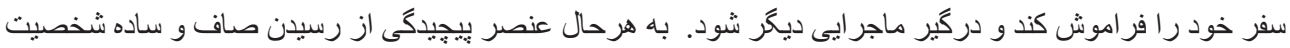

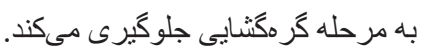

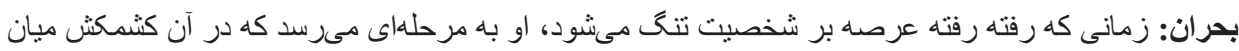

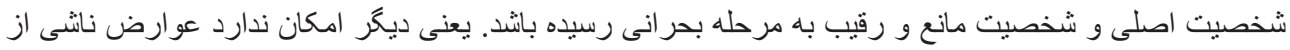

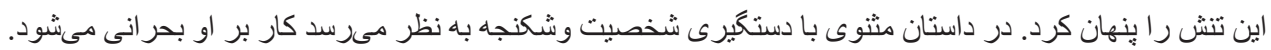

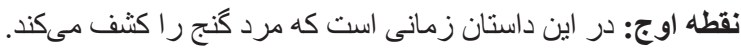

حل و فصل: زمانى است كه او به بايان اين سفر رسيده و موقعيت جديدى ران را بنا مىكند. موقعيتى كه هم نقيصأ. 
اخلاقى او رفع شدهو هم به ثروت جديدى دست يافته است. بهترين حل و فصلها زمانى رخ مىدهد كه مشكل بيرونى

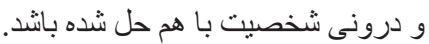

\section{تطبيث داستان با الكوى سفر نويسنده}

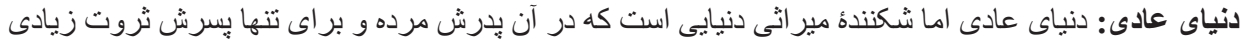

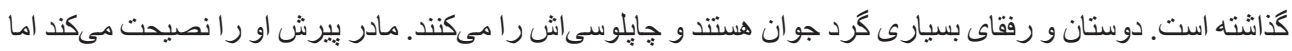

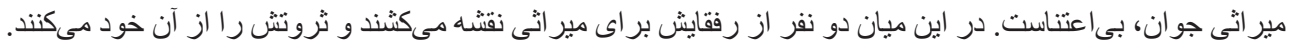

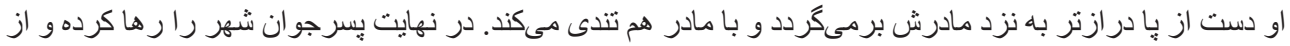

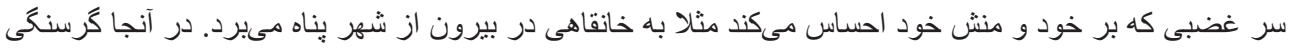

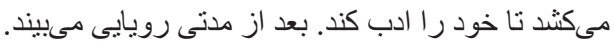

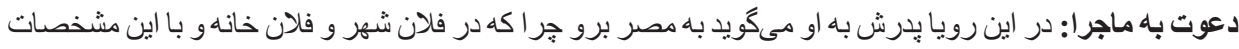

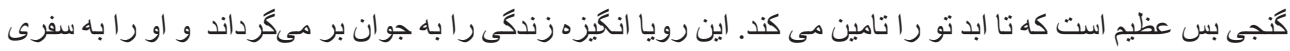

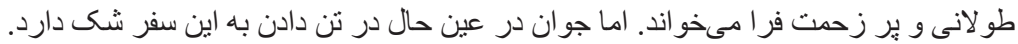

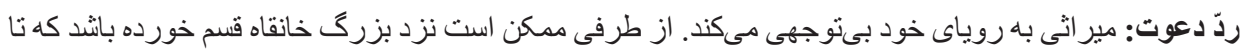

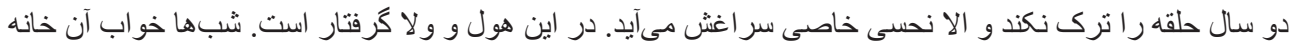

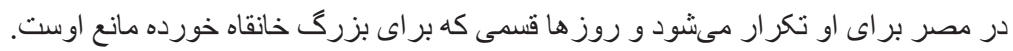

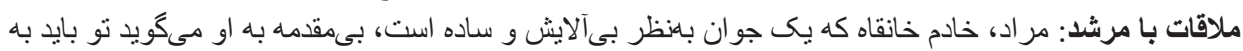

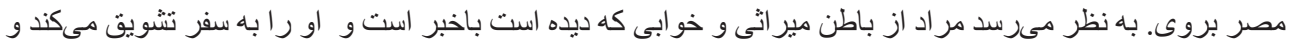

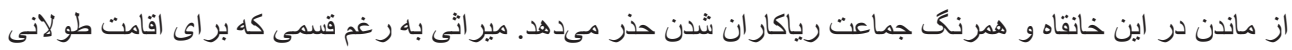

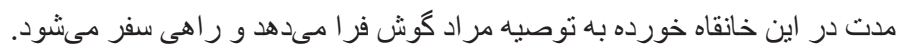

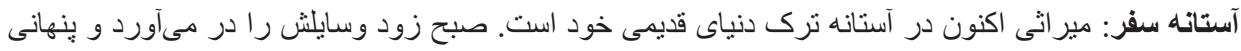

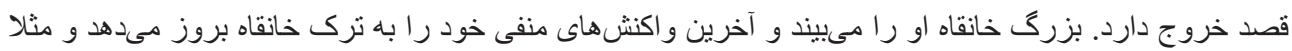

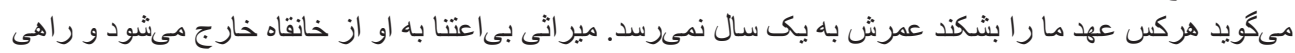
سفرى برخطر مىشود.

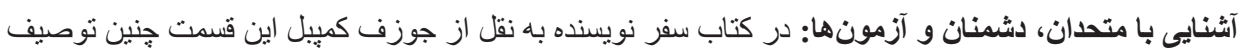

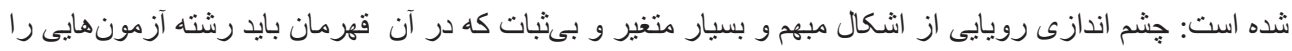
شيت سر بكذارد. در داستان مثنوى، مو لانا به مر احلى كه شخصيت در طول سفر طى كرده نبرد داخته است. يكى انتخاب آن است كه آنه

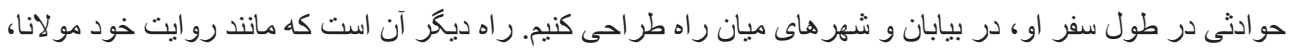

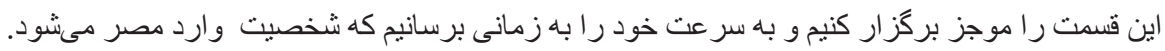

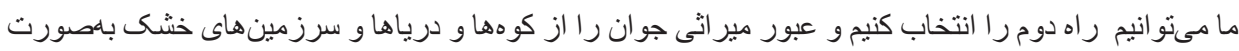

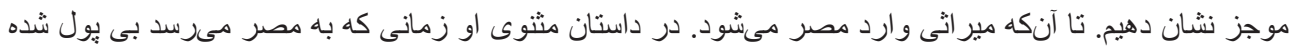

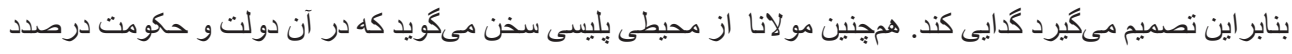

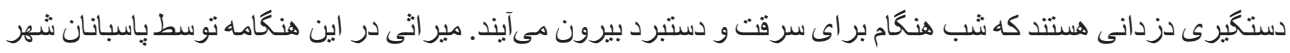

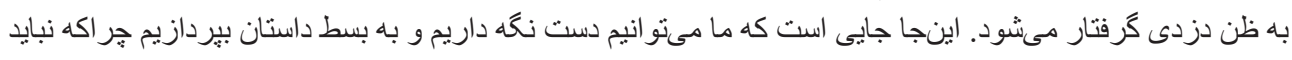

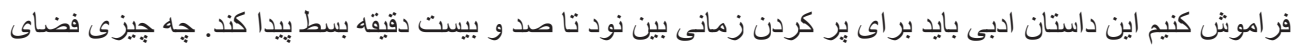

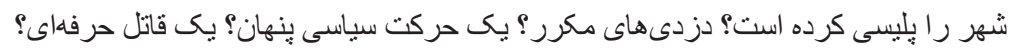




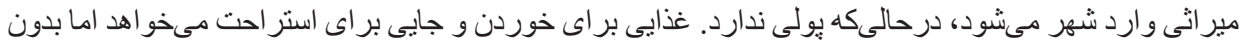

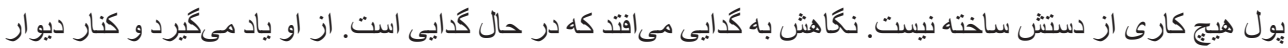

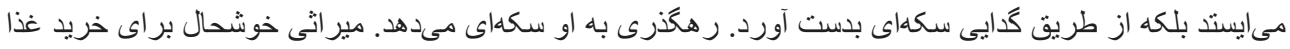

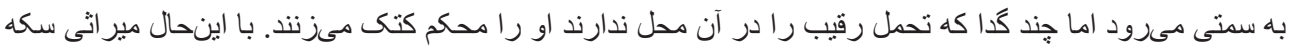

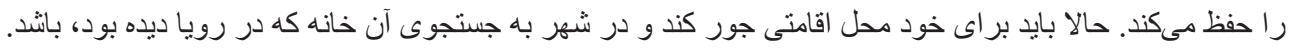

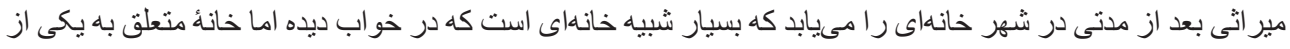

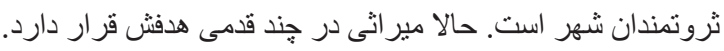

راهيابى به زُرفترين غار: در اين مرحله قهرمان مانتد كوهنوردى است كه با تلاش بخش آزمون را بڤّت سر

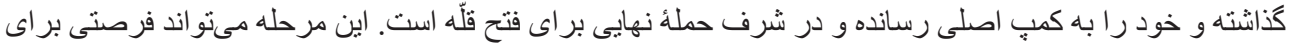

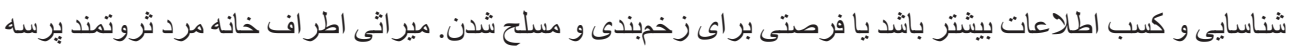

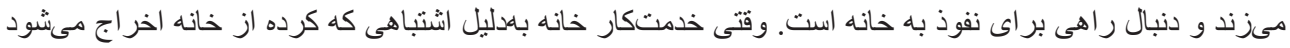

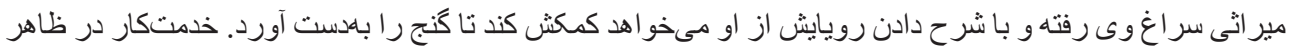

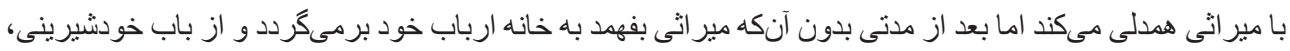

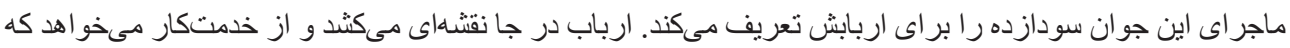

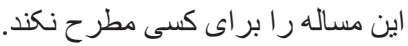

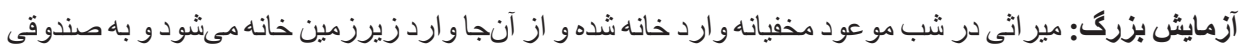

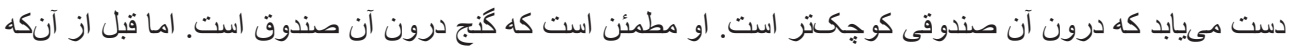

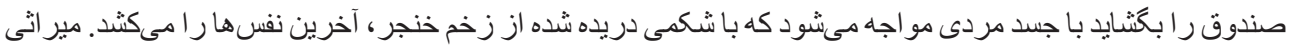

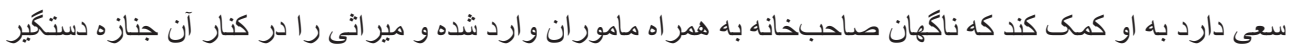

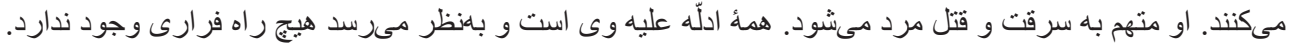

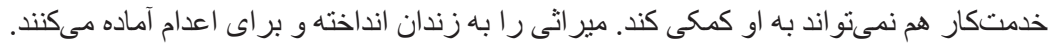

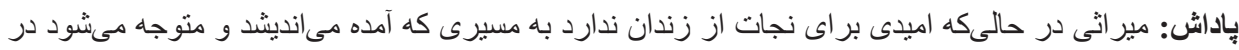

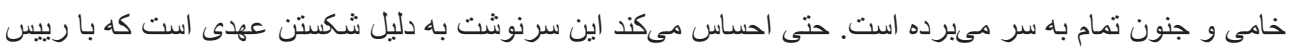

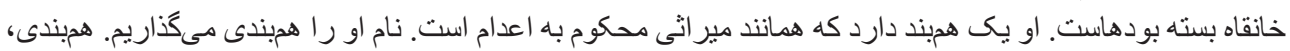

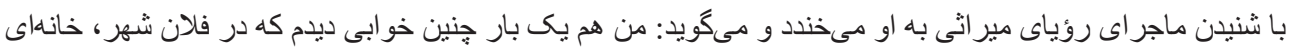

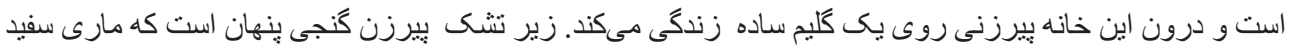

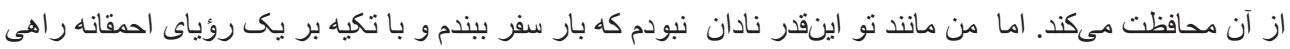

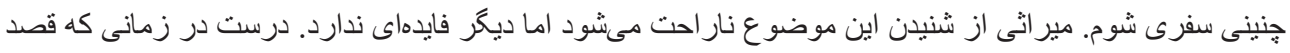

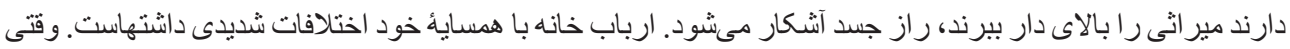

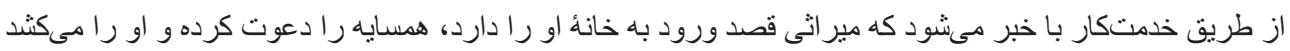

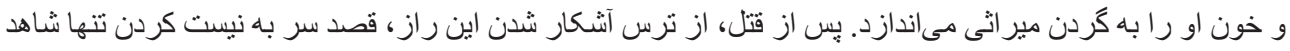

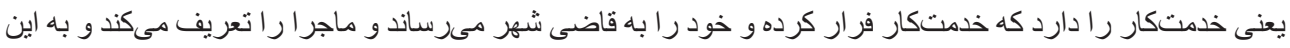

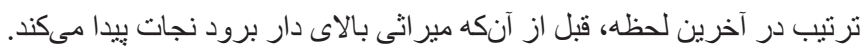

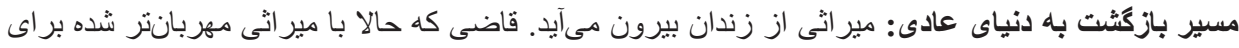

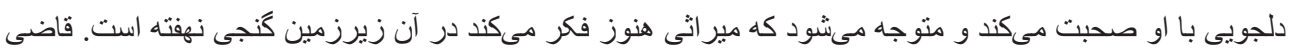

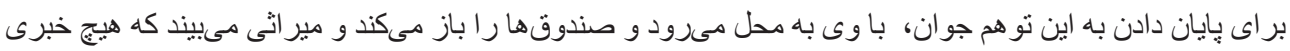

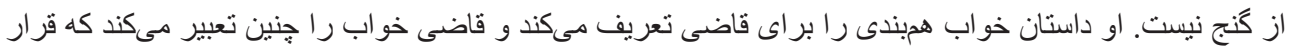




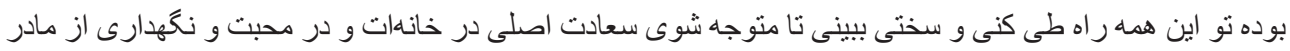

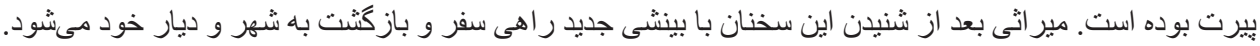

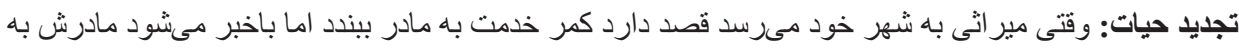

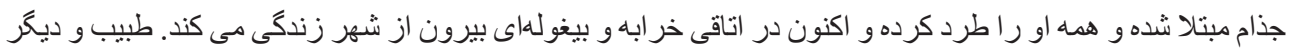

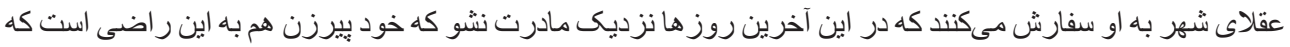

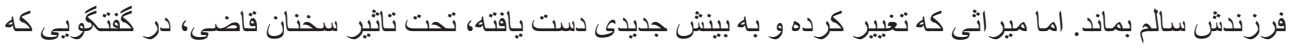

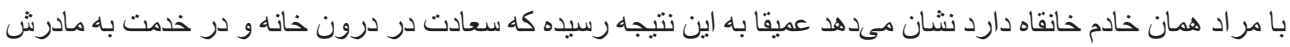

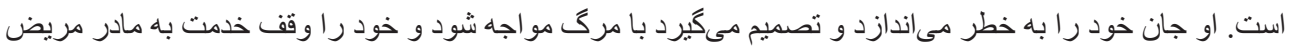

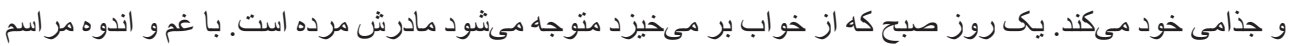

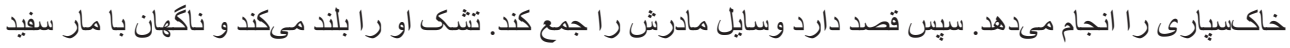

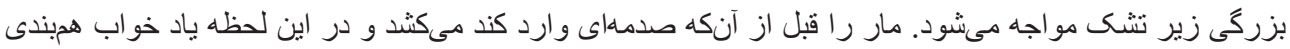

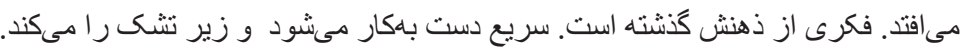

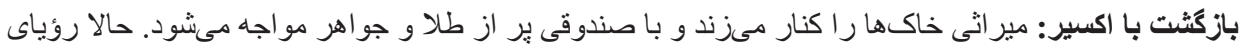

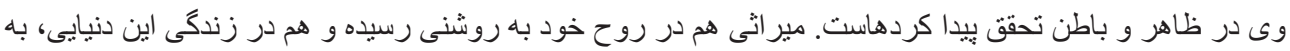

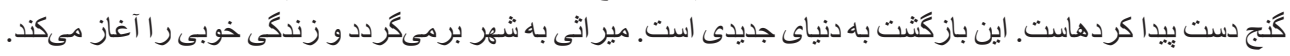

\section{تطبيق داستان با الكُوى كانتور}

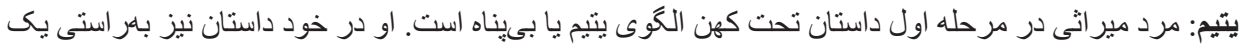

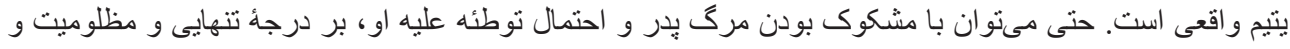

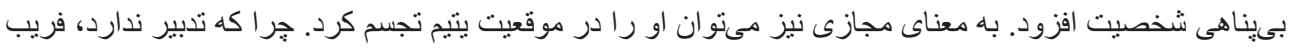

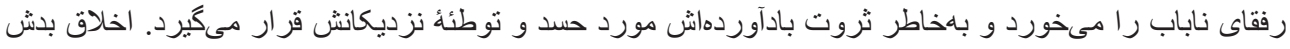

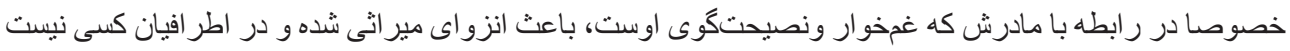

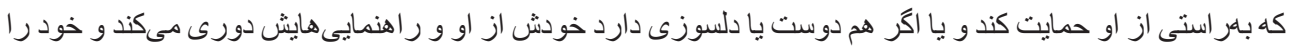

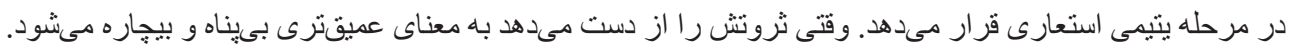

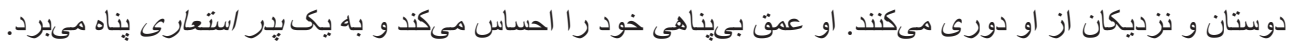

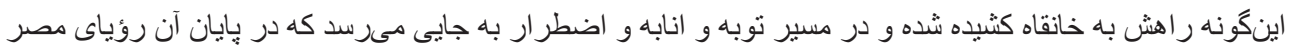

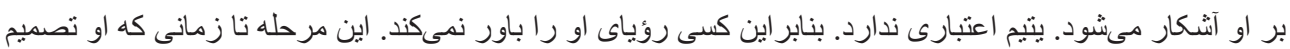

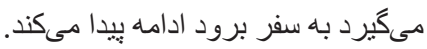

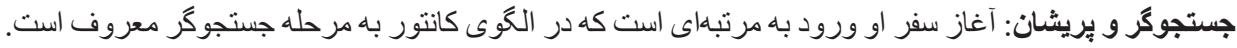

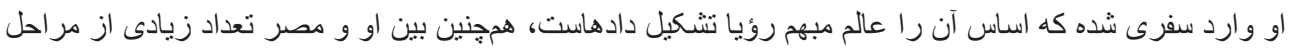

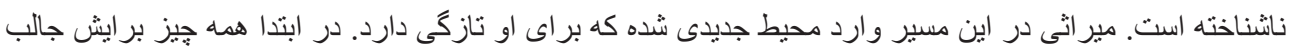

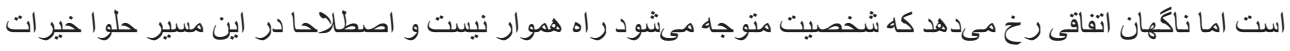

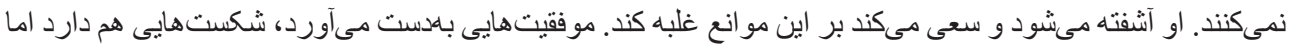

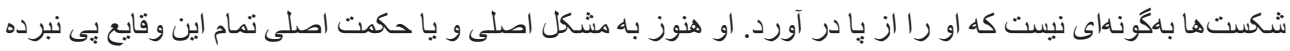

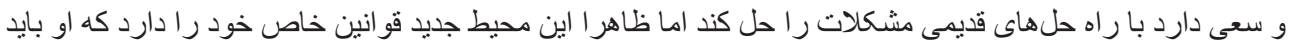

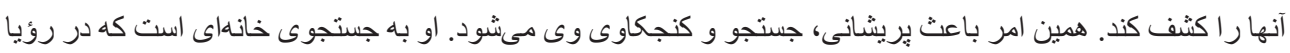

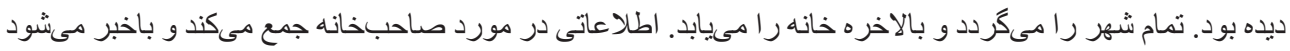

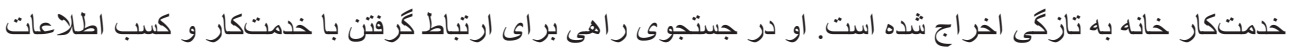


بيشتر درباره وضعيت خانه و محل كنج است. اين وضعيت در جايى اشباع مىشود. آنجا به مثابه بايان اين مرحله و زمان دست زدن به اقدامى جدى است.

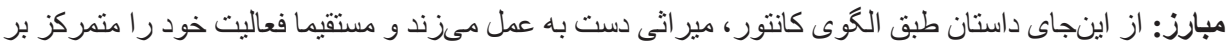

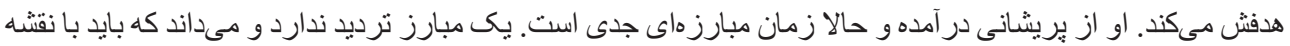

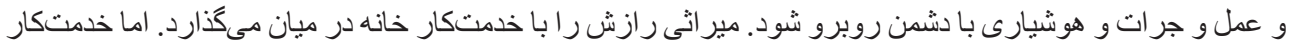

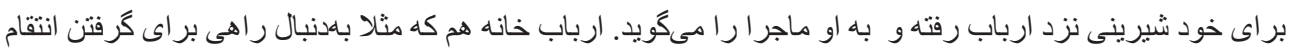

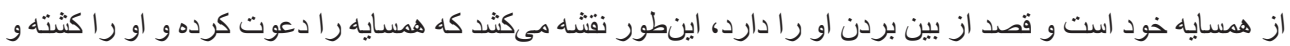

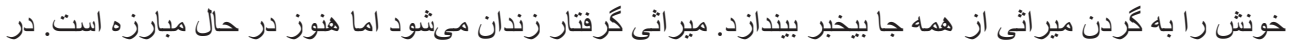

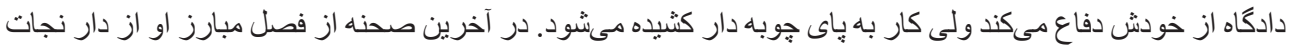

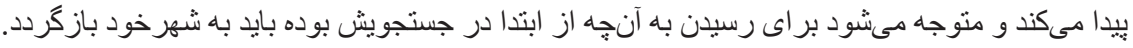

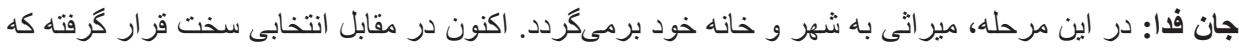

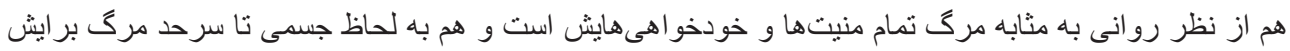

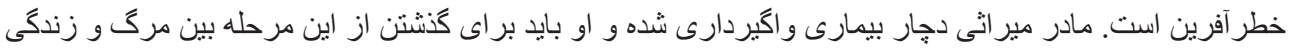

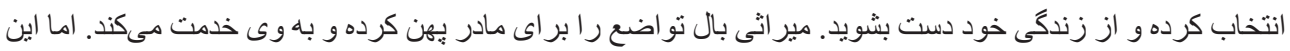

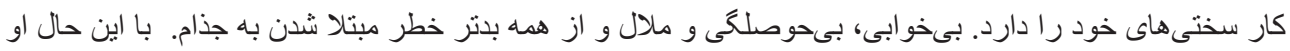

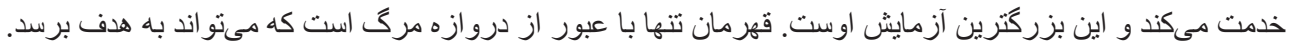

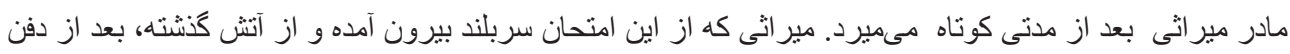

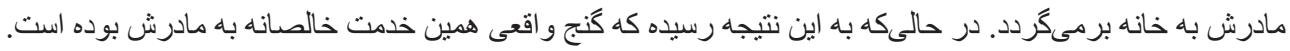

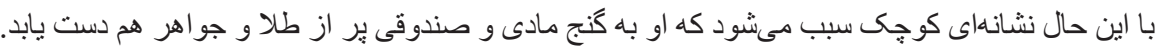

\section{الكُوى سله بِردهاى سيد فيلا}

يرده اول

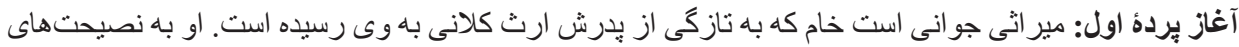

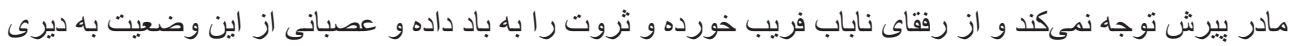
بيناه ميرد. حادثُٔ محرك: مير اثى در دير رويايى مىيبيد كه سرنوشت او را عوض مىكند. او تصميم مىكيرد براى يافتن

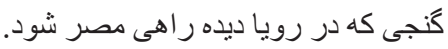
نقطة عطف اول: مير اثى بر ائ يافنن كنج از مادر خداحافظى كرده و از شهر خود خارج مىشود.

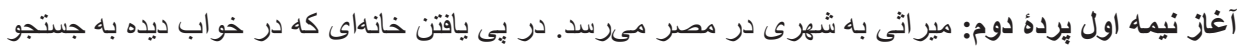

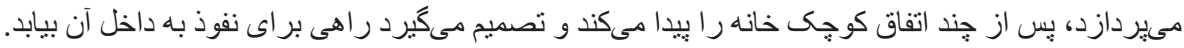

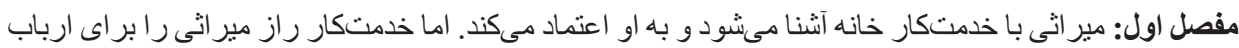

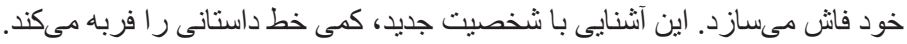

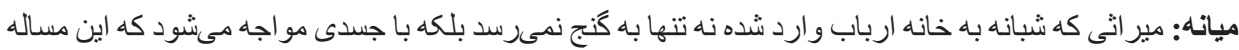

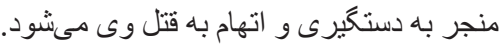

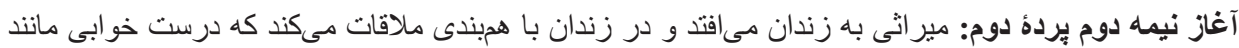


خو اب او ديده بوده است. قاضى عذر و بهانهاى مير اثى را نمىيذيرد و همه جيز در جهت اعدام او شكل مىكيرد.

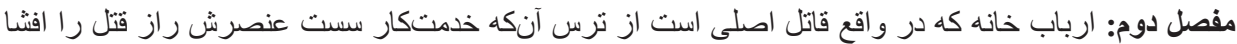

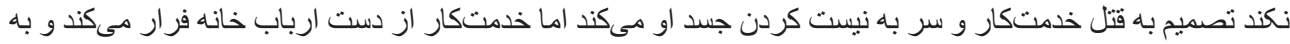

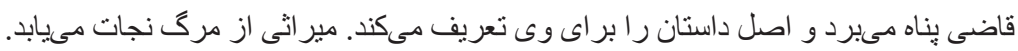

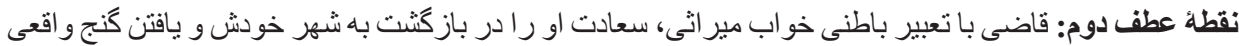

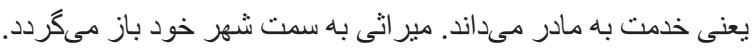

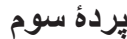

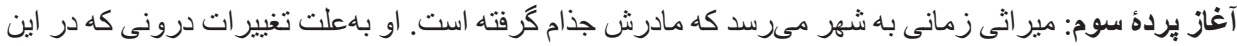

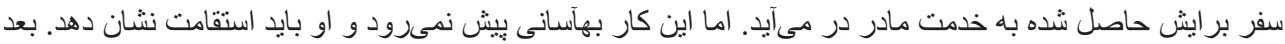

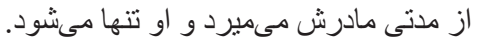

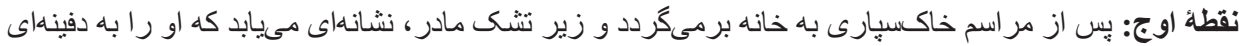
از طلا و سكههاى قيمنى مىرساند.

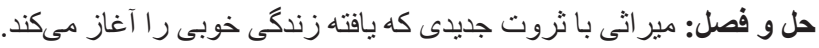

\section{نتيجهكيرى}

در نحاه اول بسيارى از مو اد و مصالحى كه در اين داستان مو لاناو ديكر داستان هاى دفتر ششم مثنوى وجود دارد،

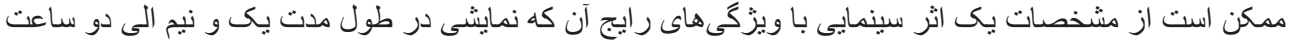

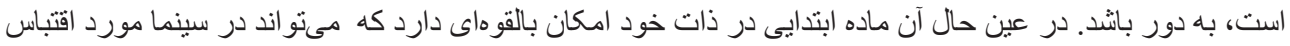

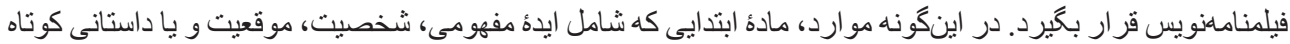

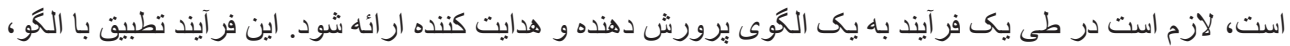

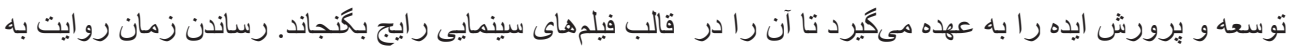
نود الى صد و بيست دقيقه در عين حفظ جذابيتى كه بايد تماشاكر را به ادامه تماشاى رو ايت سينمايى ترغيب كند، اولين

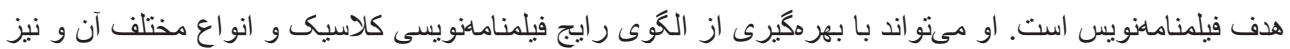

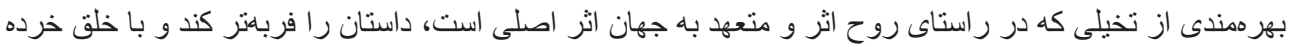

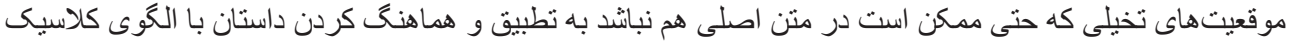

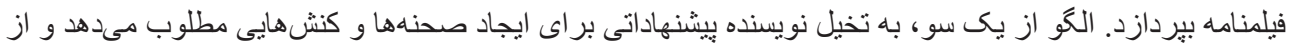

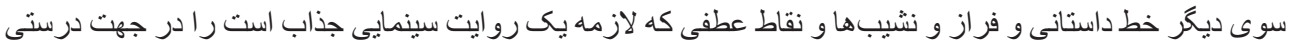

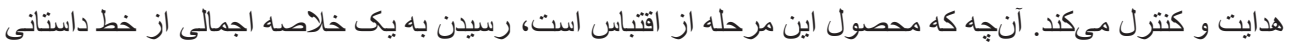

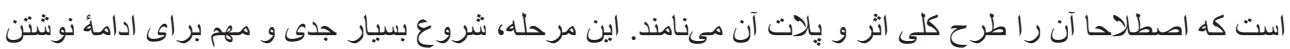
فيلمنامه است كه شامل نوشتن صحنهاو و ديالوك هاست.

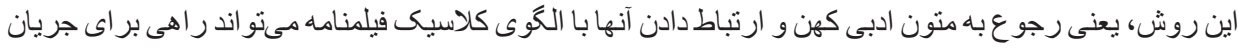

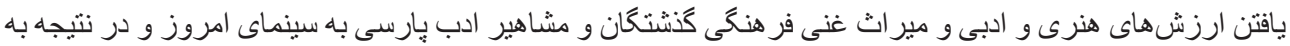

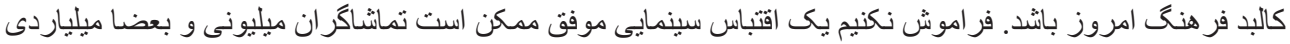

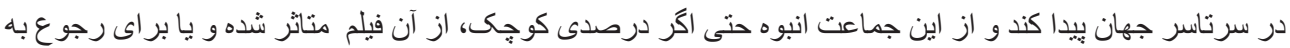

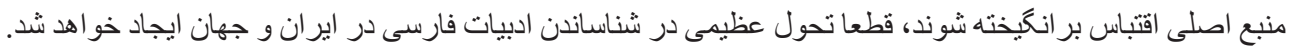




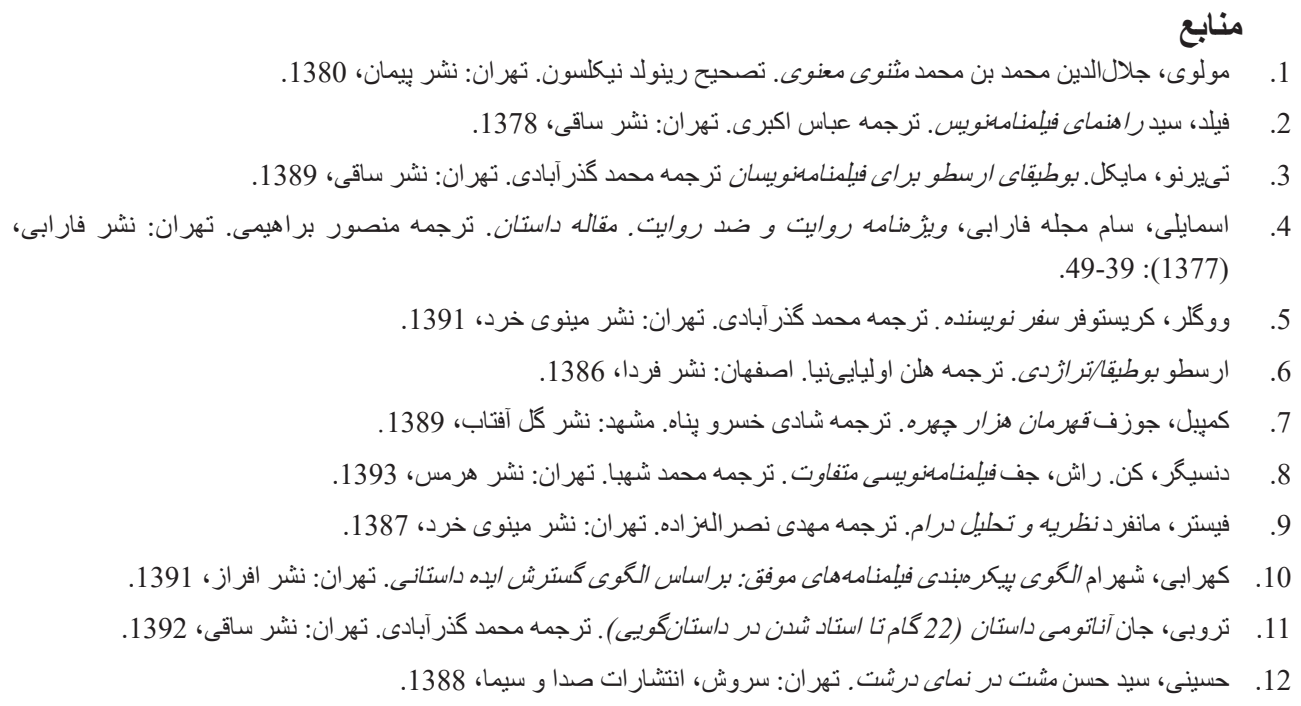

\section{References / Kaynakça}

Mevlevî, Celâleddîn Muhammed b. Muhammed. Mesnevî-yi Ma'nevî. Tashîh Reynold Nicholson. Tehrân: Neşr-î Peymân, 1380.

Field, Syd. Râhnomâ-yi Fîlmnâmenevîs. Tercome ‘Abbâs Ekberî. Tehrân: Neşr-i Sâkî, 1378.

Tierno, Michael. Poetika-yi Aristo beraî Fîlmnâmenevîsân. Tercome Muhammed Gozerâbâdî. Tehrân: Neşr-i Sâkî, 1389.

İsmâilî, Sâm, "Makâle-yi Dâstân", Mecelle-yi Fârâbî: Vîjenâme-yi Rivâyet u Zidd-i Rivâyet, Tercome Mensûr Barâhîmî. Tehrân: Neşr-i Fârâbî (1377): 39-49.

Vogler, Christopher. Sefer-i Nevîsende. Tercome Muhammed Gozerâbâdî. Tehrân: Neşr-i Mînûy-i Hired, 1391. Aristo, Poetika/Trajedi. Tercome Helen Ouliaeinia. İsfahân: Neşr-i Ferdâ, 1386.

Campbell, Joseph. Kahramân-i Hezâr Çehre. Tercome Şâdî Hosrev Penâh. Meşhed: Neşr-i Gol-i Âftâb, 1389.

Dancyger, Ken; Rush, Jeff. Fîlmnâmenevîsî-yi Motefâvet. Tercome Muhammed Şehbâ. Tehrân: Neşr-i Hermes, 1393.

Pfister, Manfred. Nazariyye u Tahlîl-i Derâm. Tercome Mehdî Nasrullahzâde. Tehrân: Neşr-i Mînûy-i Hired, 1387.

Kahrâbî, Şehrâm. Olgû-yi Peykerbendî-yi Fîlmnâmehâ-yi Movaffak: ber esâs-i Olgû-yi Gostereş-i İde-yi Dâstânî. Tehrân: Neşr-i Efrâz, 1391.

Truby, John. Ânatomî-yi Dâstân (22 Gâm tâ Ostâd Şoden der Dâstângûŷ̉). Tercome Muhammed Gozerâbâdî. Tehrân: Neşr-i Sâkî, 1392.

Hoseynî, Seyyid Hasan. Moşt der Nomâ-yi Doroşt. Tehrân: Surûş, İntişâât-i Sedâ u Sîmâ, 1388. 